\title{
Nanotechnology in agri-food production: an overview
}

This article was published in the following Dove Press journal:

Nanotechnology, Science and Applications

20 May 2014

Number of times this article has been viewed

\section{Bhupinder Singh Sekhon}

Institute of Pharmaceutical Sciences, PCTE Group of Institutes, Ludhiana, India

Video abstract

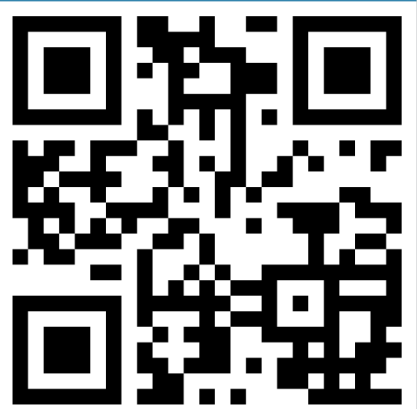

Point your SmartPhone at the code above. If you have a QR code reader the video abstract will appear. Or use: http://dvpr.es/ltEDr2z
Correspondence: Bhupinder Singh Sekhon

Institute of Pharmaceutical Sciences,

PCTE Group of Institutes, near Baddowal Cantt, Ludhiana |4202I, India

Tel +9l I6 I2888550

Email sekhon224@yahoo.com
Abstract: Nanotechnology is one of the most important tools in modern agriculture, and agri-food nanotechnology is anticipated to become a driving economic force in the near future. Agri-food themes focus on sustainability and protection of agriculturally produced foods, including crops for human consumption and animal feeding. Nanotechnology provides new agrochemical agents and new delivery mechanisms to improve crop productivity, and it promises to reduce pesticide use. Nanotechnology can boost agricultural production, and its applications include: 1) nanoformulations of agrochemicals for applying pesticides and fertilizers for crop improvement; 2) the application of nanosensors/nanobiosensors in crop protection for the identification of diseases and residues of agrochemicals; 3 ) nanodevices for the genetic manipulation of plants; 4) plant disease diagnostics; 5) animal health, animal breeding, poultry production; and 6) postharvest management. Precision farming techniques could be used to further improve crop yields but not damage soil and water, reduce nitrogen loss due to leaching and emissions, as well as enhance nutrients long-term incorporation by soil microorganisms. Nanotechnology uses include nanoparticle-mediated gene or DNA transfer in plants for the development of insect-resistant varieties, food processing and storage, nanofeed additives, and increased product shelf life. Nanotechnology promises to accelerate the development of biomass-to-fuels production technologies. Experts feel that the potential benefits of nanotechnology for agriculture, food, fisheries, and aquaculture need to be balanced against concerns for the soil, water, and environment and the occupational health of workers. Raising awareness of nanotechnology in the agri-food sector, including feed and food ingredients, intelligent packaging and quickdetection systems, is one of the keys to influencing consumer acceptance. On the basis of only a handful of toxicological studies, concerns have arisen regarding the safety of nanomaterials, and researchers and companies will need to prove that these nanotechnologies do not have more of a negative impact on the environment.

Keywords: agriculture, food, nanotechnology, nanoparticle, nanopesticides, nanosensors, smart delivery systems

\section{Introduction}

The practice of agriculture also known as "farming" is the process of producing food, feed, fiber, and many other desired products by the cultivation of certain plants and the raising of livestock. Agriculture is the backbone of most developing countries and it provides food for humans, directly and indirectly. The world's population will grow to an estimated 8 billion people by 2025 and 9 billion by 2050, and it is widely recognized that global agricultural productivity must increase to feed a rapidly growing world population. The agri-food production is of vital importance, as it has been one of the primary drivers of economy. In addition, it can offer routes to value-added crops. Agricultural practices 
are often in the public eye because climate change, energy and resource constraints, and rapidly growing global population are placing unprecedented pressure on food and water resources. The Food and Agriculture Organization of the United Nations predicts that annual meat production of 200 million tons will be required by 2050 to respond to the food needs brought about by increasing global population, ${ }^{1}$ and this predicted increasing demand for meat puts further pressure on agricultural land because farmers need to grow crops to produce animal feed. Land for food crops also faces increasing competition from the need for crops for other purposes - such as the production of biofuels and pharmaceuticals. Thus food production capacity is faced with many challenges, which include a falling ratio of arable land to population. Agriculture as a source of food is becoming increasingly important in a world of diminishing resources and an ever-increasing global population. ${ }^{2}$ Given the increasing world population, it is necessary to use the modern technologies such as nanotechnology and nanobiotechnology in agricultural and food sciences. Nanotechnology has a tremendous potential to revolutionize agriculture and allied fields, including aquaculture and fisheries. Nanoagriculture focuses currently on target farming that involves the use of nanosized particles with unique properties to boost crop and livestock productivity. ${ }^{3,4}$

Agri-food nanotechnology is multidisciplinary in nature (Figure 1). Nanotechnology application to the agriculture and food sectors is relatively recent compared with its use in drug delivery and pharmaceuticals. ${ }^{5}$ Nanotechnology has the potential to protect plants, monitor plant growth, detect plant and animal diseases, increase global food production, enhance food quality, and reduce waste for "sustainable intensification", ${ }^{6-12}$ Food and agricultural production are among the most important fields of nanotechnology application. ${ }^{13-18}$

\section{Nanotechnology and nanomaterials}

Nanoscale refers to size dimensions typically between approximately 1-100 nm (or more appropriately, 0.2-100.0 nm)

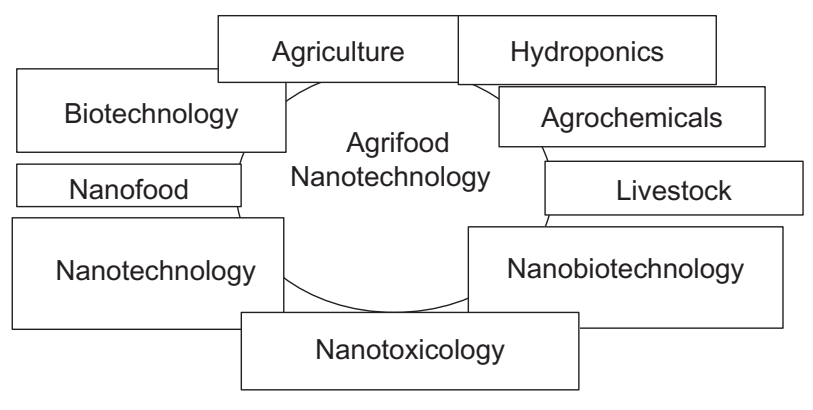

Figure I Multidisciplinary nature of agri-food nanotechnology. because it is at this scale that the properties of materials differ with respect to their physical, chemical, and biological properties from those at a larger scale. A single nanometer (nm) is 1 billionth of a meter. Nanotechnology refers to the understanding and control of matter at nanoscale, where a unique phenomenon enables novel applications. ${ }^{19}$ However, limiting size in nanotechnology to the $1-100 \mathrm{~nm}$ range excludes numerous materials and devices, especially in the pharmaceutical and agricultural fields, and some experts caution against a rigid definition based on a sub- $100 \mathrm{~nm}$ size. Any form of a material that has one or more dimensions in the nanoscale is known as nanomaterial. According to another definition, "nanomaterial" means a natural, incidental, or manufactured material containing particles in an unbound state or as an aggregate or as an agglomerate and where, for $50 \%$ or more of the particles in the number size distribution, one or more external dimension is in the range $1-100 \mathrm{~nm} .^{20}$ Materials that have one dimension in the nanoscale (and are extended in the other two dimensions) are layers, such as graphene, thin films, or surface coatings. Materials that are nanoscale in two dimensions (and extended in one dimension) include nanowire and nanotube. Materials that are nanoscale in three dimensions are particles, for example precipitates, dendrimers, fullerenes, colloids, and tiny particles of semiconductor materials (quantum dots). Nanomaterial-specific properties derive mainly from their increased relative surface area and quantum effects. Any material that is intentionally produced in the nanoscale to have specific properties or a specific composition is called a manufactured/engineered nanomaterial. Such engineered nanomaterials have different properties when compared with their conventional counterparts. A nanoparticle is a discrete entity that has all three dimensions in the nanoscale. The sizes of different organisms and molecules/biomolecules on the micrometric and nanometric scale are given in Table 1.

\section{Biological natural nanoparticles}

Biological naturally occurring nanoparticles (nanoclay, tomato carotenoid lycopene, many chemicals derived from soil organic matter, lipoproteins, exosomes, magnetosomes, viruses, ferritin) have diverse structures with wide-ranging biological roles. Biological nanoparticles are often biocompatible and have reproducible structure. Potential biomedical applications of natural and modified biological nanoparticles have been reported. ${ }^{21}$

Animals use nanotechnology, where nanostructures help animals climb, slither, camouflage, flirt, and thrive. A good example is the ordered hexagonal packed array of 
Table I Size of different organisms and molecules/biomolecules on the micrometric and nanometric scale

\begin{tabular}{|c|c|}
\hline Streptococcus & $800-10,000 \mathrm{~nm}$ \\
\hline Escherichia coli & I,300 $\times 4,000 \mathrm{~nm}$ (width $\times$ length) \\
\hline Poxvirus & $230 \times 320 \mathrm{~nm}$ (width $\times$ length) \\
\hline Tobacco mosaic virus & $15-300 \mathrm{~nm}$ \\
\hline Poliomyelitis virus & $27 \mathrm{~nm}$ \\
\hline Influenza virus & $85 \mathrm{~nm}$ \\
\hline Bacteria & $100-1,000 \mathrm{~nm}$ \\
\hline Red bood cells & $7,000-8,000 \mathrm{~nm}$ \\
\hline Phages T4 & $\begin{array}{l}24-200 \mathrm{~nm} \\
200 \times 80-100 \mathrm{~nm} \text { (length } \times \text { width })\end{array}$ \\
\hline Caudovirales - icosahedral phages & About $65 \mathrm{~nm}$ \\
\hline Inoviridae - filamentous phages & About $4-6 \mathrm{~nm}$ \\
\hline $\begin{array}{l}\text { Micro Electro Mechanical } \\
\text { (MEMS) devices }\end{array}$ & $10-100 \mathrm{~nm}$ \\
\hline Carbon nanotubes & $\mathrm{I}-3 \mathrm{~nm}$ diameter \\
\hline Single-walled carbon nanotubes & $\mathrm{I}-2 \mathrm{~nm}$ \\
\hline Multiwalled carbon nanotubes & $2-25 \mathrm{~nm}$ \\
\hline Milk fat globule diameter & $0.1-100 \mu \mathrm{m}$ \\
\hline Milk casein micelles & 20-400 nm diameter \\
\hline Milk lipoproteins & $10 \mathrm{~nm}$ \\
\hline Milk globular proteins & $3-6 \mathrm{~nm}$ \\
\hline Egg albumin & Mean size $<100 \mathrm{~nm}$ \\
\hline DNA molecule & About $2.5 \mathrm{~nm}$ wide \\
\hline Hemoglobin & $5.5 \mathrm{~nm}$ diameter \\
\hline Myoglobin & $3.5 \mathrm{~nm}$ diameter \\
\hline Cytochrome c & $3.1 \mathrm{~nm}$ diameter \\
\hline Catalase & I0.5 nm diameter \\
\hline Ferritin & I2.2 nm diameter \\
\hline Virus & $30-100 \mathrm{~nm}$ \\
\hline Protein & $5-50 \mathrm{~nm}$ \\
\hline Microtubules & $25 \mathrm{~nm}$ \\
\hline Ribosomes & $25 \mathrm{~nm}$ \\
\hline Quantum dot (CdSe) & $8 \mathrm{~nm}$ \\
\hline Dendrimers & $10 \mathrm{~nm}$ \\
\hline Zein & $200 \mathrm{~nm}$ \\
\hline Nanosensors & $<\mathrm{I}, 000 \mathrm{~nm}$ \\
\hline $\begin{array}{l}\text { The peptidoglycan layer (cell wall) } \\
\text { in Gram-positive bacteria }\end{array}$ & $20-80 \mathrm{~nm}$ \\
\hline $\begin{array}{l}\text { The peptidoglycan layer (cell wall) } \\
\text { in Gram-negative bacteria }\end{array}$ & $2-7 \mathrm{~nm}+7-8 \mathrm{~nm}$ outer membrane \\
\hline Adenosine triphosphate synthase & $10 \mathrm{~nm}$ \\
\hline Cell membrane & About $10 \mathrm{~nm}$ \\
\hline Simple molecules & $\mathrm{I}-10 \mathrm{~nm}$ \\
\hline Sugar molecule & $\mathrm{Inm}$ \\
\hline Water molecule & About $0.3 \mathrm{~nm}$ \\
\hline Hydrogen atom & $0.1 \mathrm{~nm}$ \\
\hline Atoms & $0.1-1 \mathrm{~nm}$ \\
\hline
\end{tabular}

structures in the wings of cicadas (for instance, Psaltoda claripennis Ashton) and termites (for example, family Rhinotermitidae). ${ }^{22}$ Studying nanostructured nipple arrays of moth eye facets helps to design better thin-film solar cells. ${ }^{23} \mathrm{~A}$ combination of three functions in one biological nanostructure (antiadhesive properties of insect ommatidia grating in addition to their widely accepted antireflective properties and ability to reduce glare to predators) can be exploited for the development of industrial multifunctional surfaces capable of enhancing light harvesting while reducing light reflection and adhesion. ${ }^{24}$ Butterfly wings contain nanostructures that give rise to optical effects such as iridescence, the effect of changing color when viewed from different angles. ${ }^{25}$ The tokay gecko uses nanotechnology to stick itself to trees, walls, windows, and even ceilings. Mimicking the agile gecko, researchers have created synthetic "gecko tape" with four times the sticking power of the real thing. ${ }^{26}$ It is well known that insects possess ferromagnetic resonance which is temperature dependent and that magnetic nanoparticles in social insects act as geomagnetic sensors. ${ }^{27}$

Nanotechnology promises to improve current agriculture practices through the enhancement of management and conservation of inputs in crops, animal production, and fisheries. ${ }^{28}$ In recent years, the food industry has made great progress in areas such as the improvement of new packaging products, the development of new functional products, transport and controlled release of bioactive substances, detecting of pathogens by using nanosensors and indicators, and purification of water through the use of nanoparticles. ${ }^{29,30}$ The potential for improving the effectiveness of agricultural active ingredients using nanosized particles, including functionalized nanocapsules, has been reported. ${ }^{31}$ Agricultural applications also include i) nanotechnology-enabled delivery of agriculture chemicals, ii) field-sensing systems to monitor the environmental stresses and crop conditions, and iii) improvement of plant traits against environmental stress and diseases. ${ }^{32-37}$

\section{Nanoagrochemicals}

Pesticides are commonly used in agriculture to improve crop yield and efficiency. Nanopesticides are one of a new strategies being used to address the problems of nonnanopesticides. ${ }^{38}$ Nanopesticides cover a wide variety of products, some of which are already on the market. They cannot be considered as a single entity; rather such nanoformulations combine several surfactants, polymers (organic), and metal nanoparticles (inorganic) in the nanometer size range. The lack of water solubility is one of the limiting factors in the development of crop-protecting agents. Microencapsulation has been used as a versatile tool for hydrophobic pesticides, enhancing their dispersion in aqueous media and allowing a controlled release of the active compound. Polymers often used in the nanoparticle production have been reported. ${ }^{39}$ 
First of all, polycaprolactone and poly(lactic) acid nanospheres were used for encapsulation of the insecticide ethiprole. In this case, results indicated that nanospheres do not provide a controlled release of agrochemical active ingredients but, due to their small size, they enhanced the penetration in the plant compared to the classical suspension. ${ }^{40}$ In vivo experiments carried out with Egyptian cotton leafworm Spodoptera littoralis larvae indicated that the toxicity of nanoparticles of novaluron resembled that of the commercial formulation. ${ }^{41}$

Nanomaterials serve equally as additives (mostly for controlled release) and active constituents. ${ }^{42}$ Controlled-release (CR) formulations of imidacloprid (1-(6 chloro-3-pyridinyl methyl)-N-nitro imidazolidin-2-ylideneamine), synthesized from polyethylene glycol and various aliphatic diacids using encapsulation techniques, have been used for efficient pest management in different crops. The bioefficacy of the prepared CR formulations and a commercial formulation were evaluated against major pests of soybean, namely stem fly, Melanagromyza sojae Zehntmer and white fly, Bemisia tabaci Gennadius. Most of the CR formulations of imidacloprid exhibited better control of the pests compared with its commercial formulations; however, of the CR formulations, poly(poly(oxyethylene-1000)-oxy suberoyl) amphiphilic polymer-based formulation performed better than others for controlling of both stem fly incidence and Yellow Mosaic Virus infestation transmitted by white fly. In addition, some of the developed CR formulations recorded higher yield over commercial formulation and control. ${ }^{43,44}$

CR formulations of carbofuran and imidacloprid provided better or equal control against the aphid, Aphis gossypii and leafhopper, Amrasca biguttula biguttula Ishida on potato crop, than commercial formulations. The residue of carbofuran and imidacloprid in potato tuber and soils was not detectable at the time of harvesting in any one of the formulations. ${ }^{45}$ Nanomaterials including polymeric nanoparticles, iron oxide nanoparticles, gold nanoparticles, and silver ions have been exploited as pesticides. Researchers have reported various aspects of nanoparticle formulation, characterization, effect of their characteristics, and their applications in management of plant diseases. ${ }^{46}$

Nanoparticles in insects and their potential for use in insect pest management have been reported..$^{47}$ Nanotechnology in the management of polyphagous pest Helicoverpa armigera has been reported. ${ }^{48}$ The pediculocidal and larvicidal activity of synthesized silver nanoparticles using an aqueous leaf extract of Tinospora cordifolia showed maximum mortality against the head louse Pediculus humanus and fourth instarlarvae of Anopheles subpictus and Culex-quinque fasciatus. Synthesized silver nanoparticles possessed excellent antilice and mosquito larvicidal activity. ${ }^{49}$

Nanoencapsulation helps slow release of a chemical to the particular host for insect pest control through release mechanisms that include dissolution, biodegradation, diffusion, and osmotic pressure with specific $\mathrm{pH} .{ }^{50}$ Nanoparticles loaded with garlic essential oil proved effective against Tribolium castaneum Herbst. ${ }^{51}$ The use of amorphous nanosilica as biopesticide has been reported. ${ }^{52}$ Nanocopper particles suspended in water have been used since at least 1931, in a product known as Bouisol as fungicide in the growing of grapes and fruit trees. ${ }^{53}$

In the research and development stage, nanosized agrochemicals or nanoagrochemicals are mostly nanoreformulations of existing pesticides and fungicides. ${ }^{54}$ Nanoformulations are generally expected to increase the apparent solubility of poorly soluble active ingredients, to release the active ingredient in a slow/targeted manner, and/or to protect against premature degradation. ${ }^{55}$ Nanopesticides offer a way to both control delivery of pesticide and achieve greater effects with lower chemical dose. Agrochemical companies are reducing the particle size of existing chemical emulsions to the nanoscale, or are encapsulating active ingredients in nanocapsules designed to split open, for example, in response to sunlight, heat, or the alkaline conditions in an insect's stomach. The smaller size of nanoparticles and emulsions used in agrochemicals is intended to make them more potent. Many companies make formulations that contain nanoparticles within the $100-250 \mathrm{~nm}$ size range that are able to dissolve in water more effectively than existing ones, thus increasing their activity. ${ }^{56}$ Other companies employ suspensions of nanoscale particles (nanoemulsions), which can be either water-based or oil-based and contain uniform suspensions of pesticidal or herbicidal nanoparticles in the range of 200-400 nm. Nanocapsules can enable effective penetration of herbicides through cuticles and tissues, allowing slow and constant release of the active substances. Viral capsids can be altered by mutagenesis to achieve different configurations and deliver specific nucleic acids, enzymes, or antimicrobial peptides acting against the parasites. ${ }^{57}$ Silver nanoparticles at $100 \mathrm{mg} / \mathrm{kg}$ inhibited mycelia growth and conidial germination on cucurbits and pumpkins against powdery mildew. ${ }^{58}$ Silver nanoparticles have received significant attention as a pesticide for agricultural applications. ${ }^{59}$ The potential of nanomaterials in insect pest management as modern approaches of nanotechnology, has been reported. ${ }^{60}$ 
Treatment of Bombyx mori leaves with grasserie disease with ethanolic suspension of hydrophobic alumina-silicate nanoparticles significantly reduced the viral load. ${ }^{61}$ DNAtagged gold nanoparticles are effective against Spodoptera litura and would therefore be a useful component of an integrated pest-management strategy. ${ }^{62}$ Development of nanobased viral diagnostics including kits can help to detect the exact strain of virus and identify differential proteins in healthy and diseased states during the infectious cycle and the stage of application of therapeutics to stop disease, thus increasing speed as well as power of disease detection. ${ }^{63}$

Nanosilica has been successfully employed to control a range of agricultural insect/pest and ectoparasites in animals. Such nanoparticles get absorbed into cuticular lipids (used by insects to prevent death from desiccation) by physisorption and cause insect death by physical means when applied on leaves and stem surfaces. ${ }^{64}$ Antifungal activities of polymerbased copper nanocomposites against pathogenic fungi, ${ }^{65}$ and silica-silver nanoparticles against Botrytis cinerea, Rhizoctonia solani, Calllectotrichum gloeosporioides, ${ }^{6}$ Bipolaris sorokiniana, and Magnaporthe grisea ${ }^{67}$ have been reported. Copper nanoparticles in soda lime glass powder showed efficient antimicrobial activity against gram-positive and gram-negative bacteria and fungi. ${ }^{68} \mathrm{~A}$ novel photodegradable insecticide involving nanoparticles has been reported. ${ }^{69}$

Specific nanoencapsulated pesticides will have the ability to kill targeted insects only, thereby reducing the effective dose when compared to traditional pesticides. Further, these are absorbed on the surface of the plant, facilitating a prolonged release that lasts for a longer time compared to conventional pesticides that wash away in the rain. ${ }^{70}$ Significant mortality of two insect pests, Sarocladium oryzae and Rhyzopertha dominica, after 3 days' exposure to nanostructured alumina-treated wheat was reported..$^{71}$ Halloysite nanotube has potential to be applied as a nanocontainer for encapsulation of chemically and biologically active agents such as agromedicines and pesticides. . $^{72,73}$

It is essential to remove weeds for increasing the yield of any crop and weeding using nanoherbicides is seen as an economically viable alternative. Conventional herbicides have proved highly effective in controlling weeds without damage to crops or environment. However, chemical weed management under rain-fed areas depends on the moisture availability during the application of herbicides. Lack of moisture limits the use and efficiency of the application. The nano-silicon carrier comprising diatom frustules (pore size 1-100 nm) has been used for delivery of pesticides and herbicides in plants as well as in hormonal waste-water treatment. ${ }^{74}$
CR formulation is superior to its counterpart and results in a higher yield and better crop quality. Such a formulation also finds use in active-agent herbicides, pesticides, and plant growth regulators. ${ }^{75,76}$

The potential application of a layered single-metal hydroxide, particularly zinc-layered hydroxide, as the host for the preparation of a nanohybrid compound with a tunable CR property containing two herbicides simultaneously has been demonstrated. In this context, a nanohybrid containing both herbicides (4-(2,4-dichlorophenoxy) butyrate [DPBA] and 2-(3-chlorophenoxy) propionate [CPPA]) labeled as ZCDX was found a suitable host for the CR formulation of two herbicides, namely DPBA and CPPA, simultaneously. The monophasic, well-ordered zinc-layered hydroxide nanohybrid containing two herbicides, CPPA and DPBA, was found to be composed of a higher loading of DPBA compared to CPPA between the zinc-layered hydroxide inorganic interlayers, with percentage contributions of $83.78 \%$ and $16.22 \%$, respectively. The release rate of both CPPA and DPBA was found to be different, suggesting that the anionic guest molecules' sizes and the interactions between the host and guest could control the release kinetics. ${ }^{77}$

Researchers reported a functional hybrid nanocomposite based on the intercalation of two herbicides' anions (2,4-dichlorophenoxy acetate and 4-chlorophenoxy acetate) with zinc-aluminum-layered double hydroxide. ${ }^{78} \mathrm{CR}$ formulations of nanocomposites such as 4-chlorophenoxy acetate-zinc-aluminium-layered double hydroxide and 4-dichlorophenoxy acetate-zinc-aluminum-layered double hydroxide were reported. ${ }^{79-81}$ Researchers reported manganese carbonate core-shell nanoparticles loaded with preemergence herbicide pendimethalin programmed to release smartly based upon the requirements. ${ }^{82}$

The field of nanotechnology opens up novel applications in agriculture. ${ }^{83,84}$ Nanoencapsulation is currently the most promising technology for protection of host plants against insect pests. With nanoencapsulation techniques it is possible to step down the chemical release under controlled situations, reducing the current application dosage and improving efficiency. ${ }^{85}$

Nanoparticles can be used in the preparation of new formulations like pesticides, insecticides, and insect repellants..$^{86-88}$ Researchers have reported nanosilver and titanium dioxide nanoparticle applications in management of plant diseases. ${ }^{89}$

Fungicidal efficiency of sulfur nanoparticles against two phytopathogens, Fusarium solani (isolated from an infected tomato leaf, responsible for early blight and Fusarium wilt 
diseases) and Venturia inaequalis (responsible for the apple scab disease) has been reported..$^{90}$

Pheromones are naturally occurring volatile semiochemicals and are considered ecofriendly biological control agents. Pheromones immobilized in a nanogel exhibited high residual activity and excellent efficacy in an open orchard. Environment-friendly management of fruit flies involving pheromones for the reduction of undesirable pest populations responsible for decreasing yield and crop quality has been reported. Within this scope, the preparation of a nanogel from a pheromone, methyl eugenol (Figure 2) using a low-molecular-mass gelator such as all-trans tri(p-phenylene vinylene) bis-aldoxime (Figure 3) was reported.

The nanogel formation is possible due to the self-assembly of the gelator molecules in pheromone. The nanogel offers stability at open ambient conditions, reduced evaporation and sustained release of the pheromone, easy handling and transportation without refrigeration, and reduction in the frequency of pheromone recharging in the orchard. The protocol also depicts an easy sampling technique for the trapping of the pests in a guava orchard using the nanogels. Notably the involvement of the nanogelled pheromone brought about an effective management of Bactrocera dorsalis, a prevalent harmful pest for a number of fruits, including guava. ${ }^{91}$ Researchers studied the insecticidal activity of nanostructured alumina against two insect pests, Sarocladium oryzae (L.) and Rhyzopertha dominica (F.), which are major insect pests in stored food supplies throughout the world. Significant mortality was observed after 3 days of continuous exposure to nanostructured alumina-treated wheat. Therefore, compared to commercially available insecticides, inorganic nanostructured alumina may provide a cheap and reliable alternative for control of insect pests, and such studies may expand the frontiers for nanoparticle-based technologies in pest management. ${ }^{92}$

Recent advances in nanoscale engineering have created a new class of particulate bionanotechnology that uses biomimicry to better integrate adjuvant and antigen. These pathogen-like particles can come from a variety of sources,

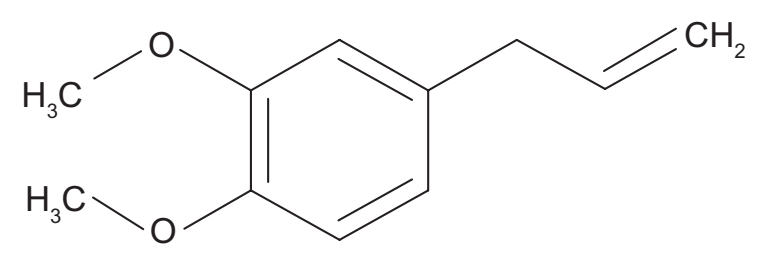

Figure 2 Methyl eugenol.

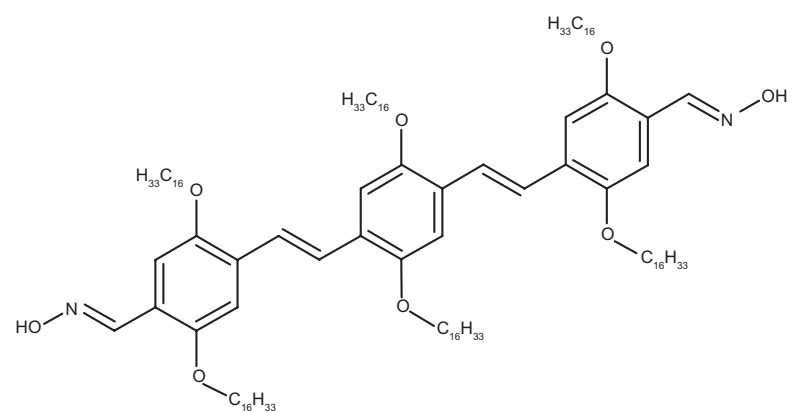

Figure 3 Molecular structure of gelator all-trans tri(p-phenylene vinylene)bisaldoxime.

ranging from fully synthetic platforms to biologically derived, self-assembling systems. By employing molecularly engineered targeting and stimulation of key immune cells, recent studies utilizing pathogen-like particles as vaccine delivery platforms have shown great promise against highimpact, unsolved vaccine targets ranging from bacterial and viral pathogens to cancer and addiction. ${ }^{93}$ Controlling pests and investigation of the plant pathology field on the basis of nanobiotechnology is challenging. ${ }^{94}$

The beneficial effects of different nanosize metals on plant cells and seed germination has also been reported. These controversial findings require clarification in order to avoid confusion to the public. However, considering these positive and negative effects of nanoparticles, it is necessary to evaluate impact of nanoparticles on plant cells, especially seeds that grow in agricultural soils. It is possible to avoid culturing sensitive plants in these areas and replace them with plants that tolerate high concentrations of nanoparticles. ${ }^{95}$

\section{Nanofertilizers}

Nanofertilizer technology is very innovative, and scant reported literature is available in the scientific journals. Substituting nanofertilizers for traditional methods of fertilizer application is a way to release nutrients into the soil gradually and in a controlled way, thus preventing autrification and pollution of water resources. ${ }^{96,97}$ Treatment with $\mathrm{TiO}_{2}$ nanoparticles on maize had a considerable effect on growth, whereas the effect of $\mathrm{TiO}_{2}$ bulk treatment was negligible. Titanium nanoparticles increased light absorption and photo energy transmission. In another experiment, a compound of $\mathrm{SiO}_{2}$ and $\mathrm{TiO}_{2}$ nanoparticles increased the activity of nitrate reductase in soybeans and intensified plant absorption capacity, making its use of water and fertilizer more efficient. ${ }^{98}$ Iranian researchers have produced the nano-organic iron-chelated fertilizer that is environmentally sustainable. Nanofertilizers have unique features like ultrahigh absorption, increase in 
production, rise in photosynthesis, and significant expansion in the leaves' surface area. ${ }^{99}$

The use of nanofertilizer leads to an increased efficiency of the elements, reduces the toxicity of the soil, to at least reach the negative effects caused by the consumption of excessive consumption of fertilizers, and reduces the frequency of application of fertilizers. ${ }^{100}$ The positive effect (uptake and the penetration of zinc oxide nanoparticles in the leaves) of zinc oxide nanoparticles on tomato plants opens an avenue for its potential use as a future nanofertilizer. Pot studies with foliar spray approach showed that plants sprayed with $20 \mathrm{mg} \mathrm{mL}^{-1}$ zinc oxide nanoparticle solution showed improved growth and biomass production as compared to control plants. ${ }^{101,102}$

Fertilizers based on nanotechnology have the potential to surpass conventional fertilizers. Innovation in nanofertilizers requires a multidisciplinary approach. In nanofertilizers, nutrients can be encapsulated by nanomaterials, coated with a thin protective film, or delivered as emulsions or nanoparticles. ${ }^{103}$ Nanobased slow-release or CR fertilizers have the potential to increase the efficiency of nutrient uptake. Engineered nanoparticles are useful for mitigating the chronic problem of moisture retention in arid soils and enhancing crop production by increasing the availability of nutrients in the rhizosphere. ${ }^{15}$ Coating and binding of nano- and subnano-composites help to regulate the release of nutrients from the fertilizer capsule. ${ }^{104}$ In this context, researchers showed that application of a nanocomposite consisting of nitrogen, phosphorus, potassium, micronutrients, mannose, and amino acids enhanced the uptake and use of nutrients by grain crops. ${ }^{105}$ Zinc-aluminium layered double-hydroxide nanocomposites have been employed for the controlled release of chemical compounds that act as plant growth regulators. Urea-modified hydroxyapatite nanoparticle-encapsulated Gliricidia sepium nanocomposite displayed a slow and sustained release of nitrogen over time at three different $\mathrm{pH}$ values. ${ }^{106}$ Nanoporous zeolite based on nitrogen fertilizer can be used as alternate strategy to improve the efficiency of nitrogen use in crop production systems. ${ }^{107}$ As superfertilizer, carbon nanotubes were found to penetrate tomato seeds and affect their germination and growth rates. Analytical methods indicated that the carbon nanotubes penetrated the thick seed coat and supported water uptake inside seeds. ${ }^{108}$ Encapsulation of fertilizers within a nanoparticle is done in three ways: the nutrient can be 1) encapsulated inside nanoporous materials, 2) coated with thin polymer film, or 3) delivered as particles or emulsions of nanoscale dimensions. ${ }^{109}$ The roles of nanofertilizers in sustainable agriculture have been reported. ${ }^{110}$

\section{Nanobiotechnology in agri-food production}

Nanobiotechnology opportunities include food, agriculture and energy applications. In the food processing industries, a few of the most common usages of nanobiotechnology in quality monitoring of food products may be enumerated as nanosensors/nanobiosensors and bacteria identification. The nanosensors can be utilized to detect the presence of insects or fungus accurately inside the stored grain bulk in storage rooms. Researchers suggested models for use of nanobiotechnology, either on a standalone basis or through complementarity with the existing technologies. ${ }^{111}$ In 2004, the researchers had been able to alter rice color from purple to green. ${ }^{53}$ Cellular "injection" with carbon nanofibers containing foreign DNA has been used to genetically modify golden rice. ${ }^{112}$ Nanobiotechnology provided industry with new tools to modify genes and even produce new organisms. This is due to the fact that it enables nanoparticles, nanofibers, and nanocapsules to carry foreign DNA and chemicals that modify genes. ${ }^{113}$ In addition, novel plant varieties may be developed using synthetic biology (a new branch that draws on the techniques of genetic engineering, nanotechnology, and informatics). In a recent breakthrough in this area, researchers completely replaced the genetic material of one bacterium with that from another - transforming it from one species to another. ${ }^{114}$ Nanotechnology possesses the potential to augment agricultural productivity through genetic improvement of plants and animals along with cellular level delivery of genes and drug molecules to specific sites in plants and animals. ${ }^{115,116}$

Using a medicinally rich vegetable crop, bitter melon, researchers demonstrated the accumulation of carbon-based nanoparticle Fullerol $\left(\mathrm{C}_{60}(\mathrm{OH})_{20}\right)$ in tissues and cells of root, stem, petiole, leaf, flower and fruit at particular concentrations, as the causal factor of increase in biomass yield, fruit yield, and phytomedicine content in fruits. Fullerol treatment resulted in increases of up to $54 \%$ in biomass yield and $24 \%$ in water content. Increases of up to $20 \%$ in fruit length, $59 \%$ in fruit number, and $70 \%$ in fruit weight led to an improvement of up to $128 \%$ in fruit yield. Further, contents of two anticancer phytomedicines, cucurbitacin-B and lycopene, were enhanced up to $74 \%$ and $82 \%$, respectively, and contents of two antidiabetic phytomedicines, charantin and insulin, were augmented up to $20 \%$ and $91 \%$, respectively. ${ }^{117}$ Chemists have successfully made DNA crystals by producing synthetic DNA sequences that can self-assemble into a series of three-dimensional triangle-like patterns. When multiple helices are attached through single-stranded sticky ends, a three-dimensional 
crystal is formed. This technique helps in improving important crops by organizing and linking carbohydrates, lipids, proteins, and nucleic acids to this crystal. ${ }^{118}$

Chemically coated mesoporous silica nanoparticles help in delivering DNA and chemicals into isolated plant cells. The coating triggers the plant to take the particles through the cell walls, where the genes are inserted and activated in a precise and controlled manner, without any toxic side or after effects. This technique has been applied to introduce DNA successfully to plants, including tobacco and corn plants. ${ }^{119-121}$

\section{Nanosensors/nanobiosensors in agri-food production}

Nanobiosensors can be effectively used for sensing a wide variety of fertilizers, herbicide, pesticide, insecticide, pathogens, moisture, soil $\mathrm{pH}$, and their controlled use can support sustainable agriculture for enhancing crop productivity. ${ }^{109}$ Precision farming, with the help of smart sensors, could increase productivity in agriculture, as this technology provides farmers with better fertilization management, reduction of inputs, and better management of time and the environment. Nanosensors and nanobased smart delivery systems could help in the efficient use of agricultural natural resources like water, nutrients, and chemicals through precision farming. Precision farming's enabling technologies include satellitepositioning systems, geographic information systems, and remote sensing devices that could remotely detect crop pests or evidence of stress such as drought. Nanosensors dispersed in the field can also detect the presence of plant viruses and other crop pathogens, and the level of soil nutrients. ${ }^{122,123}$ Levels of environmental pollution can be evaluated quickly by nano-smart dust (the use of tiny wireless sensors and transponders) and gas sensors. ${ }^{124}$ Nanobarcodes and nanoprocessing could also be used to monitor the quality of agricultural produce. ${ }^{125}$ Nanotechnology-based plant regulation of hormones such as auxin helps scientists understand how plant roots adapt to their environment, especially to marginal soils. ${ }^{126}$

The development of sensors/biosensors based on specific interactions makes atomic force spectroscopy more effective in detecting enzyme-inhibiting herbicides. A nanobiosensor based on an atomic force microscopy tip functionalized with the acetolactate synthase enzyme was successfully detected for the herbicide metsulfuron-methyl (an acetolactate synthase inhibitor) through the acquisition of force curves. ${ }^{127}$ Bionanosensors also allow the more quantification and rapid detection of bacteria and viruses, thereby increasing the safety of the food for the customer. ${ }^{128}$
Noble metal (palladium, platinum, and gold)/DNA/singlewalled carbon nanotube (SWCNT) hybrid nanostructurebased gas sensor arrays were fabricated by means of inkjet printing of metal ion-chelated DNA/SWCNTs on microfabricated electrodes, followed by electroless deposition to reduce metal ions to metal. DNA served as a dispersing agent to effectively solubilize pristine SWCNTs in water and as metal ion-chelating centers for the formation of nanoparticles. The results on the sensitivity and selectivity of the gas sensors toward various gases such as $\mathrm{H}_{2}, \mathrm{H}_{2} \mathrm{~S}, \mathrm{NH}_{3}$, and $\mathrm{NO}_{2}$ indicated the enhancement of the sensitivity and selectivity toward certain analytes by functionalizing with different metal nanoparticles (eg, Pd/DNA/SWCNTs for $\mathrm{H}_{2}$ and $\mathrm{H}_{2} \mathrm{~S}$ ). The combined responses give a unique pattern or signature for each analyte by which the system can identify and quantify an individual gas. ${ }^{129}$

Nanosensors are expected to impact agricultural, food, and environmental sectors. The Nanotechnology Signature Initiative "Nanotechnology for Sensors and Sensors for Nanotechnology: Improving and Protecting Health, Safety, and the Environment" is the fifth to be launched by agencies of the National Nanotechnology Initiative. Portable nanodevices can rapidly detect insects, diseases, pathogens, chemicals, and contaminants and can result in faster treatments. ${ }^{130}$

Nanosensors based on using electrochemically functionalized SWCNTs with either metal nanoparticles or metal oxide nanoparticles, and metal oxide nanowires and nanotubes for gases such as ammonia, nitrogen oxides, hydrogen sulfide, sulfur dioxide, and volatile organics have potential application in monitoring agricultural pollutants for the assessment of impacts of these pollutants on biological and ecological health and in increase of crop productivity and reducing land burden. Researchers addressed the fabrication, functionalization, assembly/alignment, and sensing applications of field-effect transistors based on carbon nanotubes, silicon nanowires, and conducting polymer nanowires. Further, they evaluated how such sensors have been used for detection of various biological molecules and how such devices have enabled the achievement of high sensitivity and selectivity with low detection limits. ${ }^{131}$

Nanotechnology-enabled devices will increase the use of sensors linked to global positioning systems for real-time monitoring of crops. ${ }^{132}$ In the field of sensor research and development, bionanotechnology is poised to make significant contributions and has the potential to radically alter the way sensors are designed, constructed, and implemented. Biomimetic nanosensor designs based on immobilized tyrosinase for determination of toxic compounds and smart 
biosensors for determination of mycotoxines were reported. Biosensor design showed good compatibility between membranes and enzymes without a change of the conformation of the enzyme molecule, and binding always takes place outside the enzyme active centers. ${ }^{133}$

Carbon-ceramic electrode modified with multi-walled carbon nanotubes-ionic liquid nanocomposite was used for electrochemical determination of the food dyes, sunset yellow and tartrazine, in food and beverage samples. ${ }^{134}$

\section{Nanotechnology and agri-environment}

The use of pesticides and fertilizers to improve food production leads to an uncontrolled release of undesired substances into the environment. Today, nanotechnology represents a promising approach to improve agricultural production and remediate contaminated soil and groundwater. Researchers reported the recent applications of nanotechnologies in agroenvironmental studies, with particular attention to the fate of nanomaterials once introduced in water and soil. They showed that the use of nanomaterials improved the quality of the environment and helped detect and remediate polluted sites; however, only a small number of nanomaterials demonstrated potential toxic effects. ${ }^{135}$ The impact of iron nanoparticles on terrestrial plants revealed that orangebrown complexes/plaques, formed by root systems of all plant species from distinct families tested, were constituted of nanoparticles containing iron. Further, the formation of iron nanoparticles/nanocomplexes was reported as an ideal homeostasis mechanism evolved by plants to modulate uptake of desired levels of ionic iron. ${ }^{136}$

Copper is an essential element in the cellular electrontransport chain, but as a free ion it can catalyze production of damaging radicals. Researchers showed using synchrotron microanalyses that common wetlands plants Phragmites australis and Iris pseudoacorus transformed copper into metallic nanoparticles in and near roots with evidence of assistance by endomycorrhizal fungi when grown in contaminated soil in the natural environment. ${ }^{137}$

Converting carbon dioxide to useful chemicals in a selective and efficient manner remains a major challenge in renewable and sustainable energy research. Silver electrocatalyst converts carbon dioxide to carbon monoxide at room temperature; however, the traditional polycrystalline silver electrocatalyst requires a large overpotential. A nanoporous silver electrocatalyst enables electrochemical reduction of carbon dioxide to carbon monoxide with approximately $92 \%$ selectivity at a rate (that is, current) over 3,000 times higher than its polycrystalline counterpart under moderate overpotentials of $<0.50 \mathrm{~V}$. The improved higher activity is a result of a large electrochemical surface area and intrinsically higher activity compared with polycrystalline silver. ${ }^{138}$

Growing and harvesting organic nanoparticles from plants represents an important step in the development of plant-based nanomanufacturing. ${ }^{139}$ It is a significant improvement on the exploitation of plant systems for the formation of metallic nanoparticles. An enhanced system for the production of English ivy adventitious roots and their nanoparticles by modifying GA7 Magenta boxes and identifying the optimal concentration of indole-3-butyric acid for adventitious root growth was developed. It represents a pathway for the generation of bulk ivy nanoparticles for translation into biomedical applications. ${ }^{140}$ Recent research has demonstrated that the adventitious roots of English ivy are responsible for the production of an adhesive compound composed of polysaccharide and spherical nanoparticles 60-85 $\mathrm{nm}$ in diameter. ${ }^{141,142}$ The recent advances brought into methodology for biological and ecofriendly synthesis and characterization of herbal and medicinal plant-mediated nanoparticles were reported. ${ }^{143,144}$

\section{Nanocomposites/ nanobiocomposites}

Composites made from particles of nanosize ceramics or metals smaller than $100 \mathrm{~nm}$ can suddenly become much stronger than predicted by existing materials-science models. For example, metals with a so-called grain size of around $10 \mathrm{~nm}$ are as much as seven times harder and tougher than their ordinary counterparts with grain sizes in the hundreds of nanometers. A nanocomposite is a multiphase solid material where one of the phases has one, two, or three dimensions of less than $100 \mathrm{~nm}$, or structures having nanoscale repeat distances between the different phases that make up the material. ${ }^{145-147}$

Nanocomposites are polymers reinforced with small quantities (up to $5 \%$ by weight) of nanosized particles, which have high aspect ratios and are able to improve the properties and performance of the polymer. Polymer composites with nanoclay restrict the permeation of gases. Examples of polymer nanocomposites incorporating metal or metal oxide nanoparticles utilized mainly for their antimicrobial action include nanozinc oxide and nanomagnesium oxide. ${ }^{148}$ Cellulose nanocrystals are an attractive material to incorporate into composites because they provide highly versatile chemical functionality. ${ }^{149}$

In food packaging, nanocomposites focus on the development of high barrier properties against the diffusion of 
oxygen, carbon dioxide, flavor compounds, and water vapor. Nanoclay (montmorillonite, a hydrated alumina-silicatelayered clay consisting of an edge-shared octahedral sheet of aluminum hydroxide between two silica tetrahedral layers) minerals are found abundantly in nature and might be incorporated into the packaging films. Bionanocomposites suitable for packaging applications include starch and cellulose derivatives, poly(lactic) acid, polycaprolactone, poly(butylene succinate), and polyhydroxybutyrate. ${ }^{150}$ The most promising nanoscale fillers are layered silicate nanoclays such as montmorillonite and kaolinite (a layered silicate mineral, with one tetrahedral sheet linked through oxygen atoms to one octahedral sheet of alumina octahedra).

Nanocomposites have a wide range of applications in various fields including agriculture and food packaging. The use of nanocomposites with new thermal and gas barrier properties can prolong the post-harvest life of food, and this application could facilitate the transportation and storage of food. ${ }^{151,152}$

In dry land areas, variation in amount and distribution of rainfall mainly influences the crop production. Water sorption capacity is an important characteristic for nanoclay composite super absorbents, especially when used under rainfed condition. In this context, the water-holding capacity, water absorbency, and water-retention capacity of a zinc-coated nanoclay composite cross-linked polyacrylamide polymer developed for promotion of rainfed rice crop was reported. Water-holding capacity of the soil with nanoclay composite was $8.5 \%$ more as compared to original soil. ${ }^{153}$

For agricultural applications, polymer nanocomposites are ecofriendly (ie, biodegradable and starch nanocomposites are commonly used). In this direction, the development of mulch films can be useful for farmers to retain moisture and control weeds. ${ }^{154}$

NanolokTMPT is a trademark of InMat, Inc. (Hillsborough, NJ, USA); it is a coating comprised of nanodispersed silicate in polymer resin. Addition of clays and organo-modified clays into superabsorbent formulation has generated superabsorbent hydrogel nanocomposites. ${ }^{155}$ Starch-based nanocomposite films reinforced with flax cellulose nanocrystals play an important role in improving the mechanical properties (tensile strength and Young's modulus) and water resistance of the starch-based materials. ${ }^{156}$ Synthesis and characterization of polymer nanocomposites derived from organoclay with selected thermosetting and thermoplastic polymers have been reported. ${ }^{157}$

Applications of biochar include carbon sequestration, soil amendment, and sorption of several classes of undesirable components from water, soil, or industrial processes. ${ }^{158}$ Researchers reported developing low-dose, high-efficiency biochar-nanoparticle composites, as well as initial field trial results and detailed characterization of biochar-fertilizer composite, to highlight the potential of such biochars. ${ }^{159}$ The nanoporous and hydrophobic properties of biochar portend interactions with engineered nanoparticles that are being studied toward accurate nanotoxicity risk assessment. ${ }^{160}$ Nanocomposite films of methyl cellulose incorporated with pediocin and zinc oxide nanoparticles presented antimicrobial activity against Staphylococcus aureus and Listeria monocytogenes. ${ }^{161}$

\section{Nanotechnological applications in agrowaste reduction and high- value products such as biofuels}

Currently, the discouraging energy trends and challenges are a result of overreliance on limited fossil fuels tied with ever-increasing energy demand. Among the solutions is the nanotechnology approach to help in the smooth transition to alternative and renewable energy sources. The use of nanotechnology in transesterification, gasification, pyrolysis, and hydrogenation, as well as in the reforming of biomassderived compounds has been reported. ${ }^{162}$ Cellulose-based nanomaterials have been of increasing interest as potential nanoreinforcing filler into biocomposites for industrial and biomedical applications. ${ }^{163}$ Nanomaterials could stimulate microorganism metabolism. In such a situation, the use of nanomaterials could improve the efficiency of the lipid extraction and even accomplish it without harming the microalgae. Nanomaterials such as calcium oxide and magnesium oxide nanoparticles have been used as biocatalyst carriers or as heterogeneous catalysts in oil transesterification to biodiesel. The advances in application of nanotechnology in microalgae lipid accumulation, extraction, and transesterification were reported. ${ }^{164}$

Nanotechnologies are among the appropriate technologies for the biofuels of the future. Most of the current effort in second-generation conversion to liquid biofuels is based on biomass cellulosics to ethanol and biodiesel. The future supply of biofuels must be of such a scale that nonfood feedstocks and new technologies are intensively employed. ${ }^{165,166}$

\section{Nanotechnology in hydroponics}

Hydroponics (a branch of agriculture) is the technology of growing plants without soil and is widely used around the globe for growing food crops. ${ }^{167}$ Hydroponics technology 
in food production is less well known despite the fact that many fruits and vegetables on display in supermarkets are grown hydroponically. The most popular crops grown hydroponically are tomatoes, cucumbers and sweet peppers, melons, lettuce, strawberries, herbs, eggplant, and chillies. Other applications include the production of fodder and biofuel crops. Scientists have exploited hydroponics in nanotechnology by "growing" metal nanoparticles in living plants. ${ }^{168-170}$

Nutrient management in agricultural production is increasingly important and is more effective in hydroponic than in soil-based production. ${ }^{171}$ A nanophosphor-based electroluminescence lighting device has the potential to reduce energy costs significantly. ${ }^{172}$ Such nanotechnology-based light could reduce energy costs and encourage photosynthesis in indoor, hydroponic agriculture. ${ }^{173}$

\section{Nanotechnology in organic agriculture}

An International Federation on Organic Agriculture Movements Position Paper on the Use of Nanotechnologies and Nanomaterials in Organic Agriculture rejected the use of nanotechnology in organic agriculture. ${ }^{174}$ However, Nano Green Sciences, Inc. sells a nanopesticide that they claim is organic. ${ }^{175}$ Canada has banned nanotechnology in organic food production. An amendment was added to Canada's national organic rules banning nanotechnology as a "Prohibited Substance or Method". ${ }^{176}$

\section{Nanotechnology for crop improvement}

An enhanced production has been observed by foliar application of nanoparticles as fertilizer. ${ }^{177} \mathrm{~A}$ variety of nanomaterials, mostly metal-based nanomaterials and carbon-based nanomaterials, have been exploited for their absorption, translocation, accumulation, and particularly, effects on growth and development in an array of crop plants. ${ }^{178,179}$ The positive morphological effects included enhanced germination percentage and rate; length of root and shoot, and their ratio; and vegetative biomass of seedlings in many crop plants, including corn, wheat, ryegrass, alfalfa, soybean, rape, tomato, radish, lettuce, spinach, onion, pumpkin and cucumber. Enhancement of many physiological parameters such as enhanced photosynthetic activity and nitrogen metabolism by metalbased nanomaterials in a few crops including soybean, ${ }^{180}$ spinach, ${ }^{181-185}$ and peanut ${ }^{186}$ were also reported. Recently, researchers showed that SWCNTs containing cerium nanoparticles passively transport and irreversibly localize within the lipid envelope of extracted plant chloroplasts, promoted over three times higher photosynthetic activity than that of controls, and enhanced maximum electron transport rates. ${ }^{186}$ Nanobiotechnology provides the tool and technological platforms to advance agricultural productivity through genetic improvement of plants and delivery of genes and drug molecules to specific sites at cellular levels. The interest is increasing with suitable techniques and sensors for precision in agriculture, natural resource management, early detection of pathogens and contaminants in food products, and smart delivery systems for agrochemicals like fertilizers and pesticides. ${ }^{187}$ The genetic implications of nanoparticle-induced positive changes have been validated through decreased oxidative stress to spinach chloroplast under ultraviolet-B radiation $^{188}$ by nano-titanium dioxide, generational transmission of fullerol through seeds in rice ${ }^{189}$ and changes in gene expression at plant and cellular level in tomato and tobacco ${ }^{190,191}$ by multiwalled carbon nanotubes. However, there is only one report on the improvement of agronomic traits that documented increased leaf and pod dry weight and grain yield of soybean by exposure to nano-iron oxide. ${ }^{192}$

Germinating maize seeds in the presence of magnetic fluid followed by exposure to electromagnetic field was observed to cause a pronounced increase in nucleic acid level due to the regeneration reactions of plant metabolism processes. ${ }^{193}$

Magnetic nanoparticles coated with tetramethylammonium hydroxide led to an increase in chlorophyll-a level in maize. ${ }^{194}$ Use of iron oxide in pumpkin was also observed to increase root elongation that was attributed to the iron dissolution. ${ }^{195}$

Spent tea (solid waste) could be used for the production of biodiesel, bioethanol, and also hydrocarbon fuel gases. Researchers reported three steps for the conversion of spent tea (Camellia sinensis) into biofuels. First of all, spent tea was gasified using cobalt nanocatalyst at $300^{\circ} \mathrm{C}$ and atmospheric pressure. This catalytic gasification of spent tea yielded $60 \%$ liquid extract, $28 \%$ fuel gases, and $12 \%$ charcoal. Gaseous products contain $53.03 \%$ ethene, $37.18 \%$ methanol, and $4.59 \%$ methane. In the second step of the experiment, liquid extract of spent tea obtained from gasification, on transesterification gave $40.79 \%$ ethyl ester (biodiesel). In the third step, Aspergillus niger's growth on spent tea produced $57.49 \%$ bioethanol. The world today is consuming several million tons of tea yearly. The present technology could be utilized to produce alternate energy. ${ }^{196}$

\section{Nanofiltration}

Nanotechnology has played a very important role in developing a number of low-energy alternatives, among which 
three are most promising: 1) protein-polymer biomimetic membranes; 2) aligned-carbon nanotube membranes; and 3) thin-film nanocomposite membranes. ${ }^{197,198}$

Water purification using nanotechnology exploits nanoscopic materials such as carbon nanotubes and alumina fibers for nanofiltration. Nanofiltration is a relatively recent membrane filtration process used mostly to remove solids, including bacteria and parasites, in surface and fresh groundwater. The solar-powered system uses nanofiltration membranes to treat the local brackish (saline) water, resulting in high-quality desalinated irrigation water. The results of the Josefowitz Oasis Project indicated that irrigation with desalinated water yields higher productivity from water and inorganic fertilizers compared with current practices. Crops grown with desalinated water required $25 \%$ less irrigation and fertilizer than brackish water irrigation. In addition, in some cases, the yield of crops increased. ${ }^{199}$

Monodisperse magnetite nanocrystals have a strong and irreversible interaction with arsenic while retaining their magnetic properties. ${ }^{200}$ Nanoporous graphene can effectively filter sodium chloride salt from water and the water permeability of this material is several orders of magnitude higher than conventional reverse osmosis membranes. ${ }^{201}$ Researchers reported a nanofiltration solar desalination system for arid land agriculture. ${ }^{202}$ Nanosieves save energy in biofuel production. $^{203}$

\section{Nanofoods}

The agri-food industries have been investing huge money into nanotechnology research. Food is nanofood when nanoparticles or nanotechnology techniques or tools are used during cultivation, production, processing, or packaging of the food. It does not mean atomically modified food or food produced by nanomachines. ${ }^{204}$ Nanotechnology may hold the key to solving many critical issues facing the world's food supply today. Nanotechnology can provide manipulation of food polymers and polymeric assemblages to provide tailor-made improvements to food quality and food safety. ${ }^{205}$ Further, foods among the nanotechnology-created consumer products coming onto the market include a brand of canola cooking oil called Canola Active Oil (Shemen Industries, Tel Aviv, Israel), a tea called Nanotea (Qinhuangdao Taiji Ring Nano-Products Co., Ltd., Hebei, People's Republic of China), and a chocolate diet shake called Nanoceuticals Slim Shake Chocolate (RBC Life Sciences Inc., Irving, TX, USA). The canola oil contains an additive called "nanodrops" designed to carry vitamins, minerals, and phytochemicals through the digestive system and urea. ${ }^{206}$ The shake, according to its manufacturer, uses cocoa-infused "NanoClusters" to enhance the taste and health benefits of cocoa without the need for extra sugar. Nanotechnology will replace many fields with tremendous application potential in the area of dairy and food sectors. ${ }^{207}$

Nanotechnology is the basis of many novel and functional foods, and food colors, flavors, and textures can all be manipulated and altered at the nanoscale level. Much less nanoparticulate salt gives the same salty taste to foodstuffs as conventionally sized salt grains.

Nanotechnology-based GuardIN Fresh (Fayetteville, AR, USA) benefits perishable produce and floral products by scavenging the ethylene gas that hastens ripening. ${ }^{208}$ TopScreen DS13 (TopChim, Wommelgem, Belgium) is an easily recyclable water-based coating that contains a biopolymer with a monodisperse distribution of nanoparticles with a regular shape. This coating technology was developed to replace hard-to-recycle wax-emulsion coatings for water barriers in paper and board packaging. Paper and cardboard coated with TopScreen DS13 is as easily repulpable as nontreated paper or cardboard. By its very nature, this biopolymer has no negative impact on the recyclability or biodegradability of the packaging. ${ }^{209}$ NanoCeram-PAC (The Aquarian Environmental Group Pty Ltd., Sydney, Australia) offers a much greater external surface area that results in much more rapid adsorption of soluble contaminants that may cause unpalatable taste and odor. ${ }^{210}$

Nanotechnology has the potential to impact food processing significantly. ${ }^{211} \mathrm{~A}$ combination of antibacterial agents and nanosilver could prove to be more potent due to broadened antibacterial spectrum with possibly lower doses. To achieve this, a facile single-step green method of synthesizing silver nanoparticles functionalized with an antibacterial peptide from a food-grade lactic acid bacterium has been reported. The synthesized enterocin-coated silver nanoparticles showed broad-spectrum inhibition against a battery of food-borne pathogenic bacteria without any detectable toxicity to red blood cells. ${ }^{212}$ Nanoporous ceramic pellets can be added to the frying oil to prevent oil molecules from clumping together while in use. Moreover, they extend the useful life span of the oil. ${ }^{213,214}$ Imperm (Eastman Chemical Co., Kingsport, TN, USA), a nanocomposite of nylon and nano-clay, ${ }^{215}$ can help keep the oxygen out and the carbonation in. Beer in nanocomposite bottles can keep for as long as 30 weeks. ${ }^{216}$ Melamine contaminations in dairy products were reported in 2008 from the People's Republic of China. A quick and easy way to detect melamine in milk using gold nanoparticles 
has been reported. In the presence of melamine, the mixture changes from pink to blue. ${ }^{217,218}$

Intelligent or smart packaging communicates the quality of the food within the package through devices either incorporated into the packaging or attached to the packaging. Potential nanosensors could indicate temperature, freshness, ripeness, and contaminant/pathogen status on the package. ${ }^{219,220}$ Nanoparticles added to feed mimic cell surfaces inside the chicken. This may be due to the fact that tiny pathogens (germs) get confused and bind to the nanoparticles instead of real cells, then "flush" out as they go through the digestive system - keeping chickens safer and healthier for human consumption. .21,222 $^{2}$

An optimized amperometric immunobiosensing strip has been developed to detect foodborne pathogens. Conjugating secondary enzyme-labeled antibodies with gold nanoparticles had the ability to detect Listeria monocytogenes at $2 \log$ colony-forming unit $(\mathrm{CFU}) / \mathrm{g}$ in wild blueberry samples and exhibited significant specificity over other enteric pathogens such as Escherichia coli O157:H7 and Salmonella typhimurium. These results indicate that modifying the electrodes with gold nanoparticles is crucial in the development and production of surface plasmon-coupled emission biosensors. ${ }^{223}$

Engineered nanostructures as novel electron transfer devices for biological and agricultural applications including food and water safety, bioconversion, environmental remediation, and biosecurity have been reported. ${ }^{224}$ Nanoclay-embedded plastics allow less air and water vapor to pass, which means drinks stay fizzier and grains stay drier. Nanoclay-embedded plastics were found to be up to 100 times stronger than regular plastics and only a few percent heavier.

Addition of nanoclays to dairy packages prevented the diffusion of air into the product, thereby increasing the durability of the product without adding any chemicals to it. Such nanomaterial addition to milk packages also increased the durability of the milk 3 to 9 days. Nanowax for fruits caused higher durability and transparency. 225

Bacteriocins are antibacterial proteins produced by bacteria that kill or inhibit the growth of other bacteria. Many lactic acid bacteria produce a high diversity of different bacteriocins. Though these bacteriocins are produced by lactic acid bacteria found in numerous fermented and nonfermented foods, nisin is currently the only bacteriocin widely used as a food preservative. 226

Combined effect of food preservative agent with nanoparticles against food spoiling organisms such as
Micrococcus luteus, Bacillus cereus, Staphylococcus aureus, and Escherichia coli was reported. Here, results revealed that the producer organism producing peptides (bacteriocin) have more antimicrobial activity against the above mentioned food-spoiling organisms, when used in combination and alone, than commercially available nisin with gold nanoparticles. ${ }^{227}$

\section{Nanotechnology in animal production/reproduction and animal nanofeed applications}

Improving the feeding efficiency and nutrition of agricultural animals, minimizing losses from animal diseases, and turning animal by-products and waste and environmental concerns into value-added products are among applications of nanotechnology in animal husbandry. ${ }^{228}$

Surface-functionalized nanomaterials and nanosized additives can bind and remove toxins or pathogens. Nanofeed (a food supplement for animals) encourages the activation of the animal's own self-healing forces, equal to improved resistance against diseases. Nanofeed also acts as an antioxidant to maintain healthy cell activity and overall animal health. Benefits can be seen in the reduction of antibiotics needed, improved bone growth, improved phosphate utilization, and reduction in mortality rates. ${ }^{229}$ Zinc oxide in piglet feed prevents diarrhea in young piglets to ensure minimum weight loss and generally better performance. However, the high dosage of zinc oxide needed for sufficient effects results in a high level of excretion in the environment. The nanoproduct Fra ZN C4 (Framelco, Raamsdonksveer, the Netherlands) Dry, a nanocoated zinc oxide, ensures minimum weight loss at lower dosage with less environmental excretion. ${ }^{230}$ The results of a study of the effect of silver nanoparticles used as an additive in diets for weanling pigs on the digestive microbiota and gut morphology, and in productive performances and silver retention in tissues, suggested that silver effect may be mediated through its antimicrobial properties, either by acting against certain bacterial groups or just reducing the microbial load of the small intestine. ${ }^{231}$ Silver nanoparticles could be applied to animal feeding ${ }^{232}$ and are also a potent antimicrobial agent for use in broiler chickens. ${ }^{233}$ Magnetic nanoparticles were found successful for the recovery of aflatoxin B1 and zearalenone from feed utilizing monoclonal antibodies against aflatoxin B1 and zearalenone. ${ }^{234}$

The US Department of Agriculture and Clemson University have developed a chicken feed containing bioactive polystyrene nanoparticles that bind with harmful bacteria to reduce food-borne pathogens. ${ }^{235}$ Nanoclays (for example, 
modified montmorillonite nanocomposite) ameliorate the deleterious effects of aflatoxin on poultry. ${ }^{236}$

Reproductive performance of livestock animals influences the productivity of agriculture worldwide. ${ }^{237}$ Artificial insemination technology has great potential to improve livestock reproductive efficiency. In this context, both sire-fertility testing and semen purification can potentially be improved through the application of nanotechnology. The identification of biomarkers - for example, ligands of lectins from Arachis hypogaea and Lens culinaris, sperm proteins ubiquitin and post-acrosomal, WW domainbinding protein - and trials of nanoparticle-based technologies for fertility testing and the nanopurification of bull semen for commercial artificial insemination have been reported. ${ }^{238}$

Nanotechnology may serve the purposes of vegetarians who are willing to eat high proteinous food without killing the animals, in the form of in-vitro meat, cultured meat, or laboratory-grown meat. In the quest to maintain nutritional quality while achieving the quantities needed to fill the stomachs of hungry people in the coming years, nanotechnology may be the modern weapon. The transportability of livestock products with freshness is a great concern that may be ameliorated by the use of nanoparticles in the form of flexible pouches, laminates, and edible coatings. ${ }^{239}$

\section{Nanotechnology in poultry production}

Nanoparticles' use can produce poultry products at a much faster pace with high safety. ${ }^{239}$ The antimicrobial properties of nanobiotic-silver, when used in poultry nutrition, may affect microbial populations without inducing microbial resistance. Furthermore, nanobiotic silver may increase anabolic activities. Gold nanoparticle-based diagnosis kits detect poultry suffering from influenza virus. ${ }^{240}$

Ply500 formulations were prepared by three facile routes: covalent attachment onto US Food and Drug Administration-approved silica nanoparticles (SNPs); incorporation of SNP-Ply500 conjugates into a thin poly(hydroxyethyl methacrylate) film; and affinity binding to edible crosslinked starch nanoparticles via construction of a maltose-binding protein fusion for the surface incorporation of the listeria bacteriophage endolysin Ply500. These Ply500 formulations were found effective in killing Listeria innocua (a reduced pathogenic surrogate) at challenges up to $10^{5} \mathrm{CFU} / \mathrm{mL}$, both in non-growth-sustaining phosphate buffered saline as well as under growth conditions on lettuce. ${ }^{241}$

\section{Nanotechnology for aquaculture and fisheries}

Aquaculture plays an important role in global food production. The world's fastest growing area of animal production is the farming of fish, crustaceans and mollusks and the highly integrated fish farming industry may be among the first to incorporate and commercialize nanotech products. Aquaculture is the farming of fish and seafood and is one of the fastest growing sectors of the animal food producing sector. ${ }^{242}$ Nanotechnology has a wide usage potential in aquaculture and seafood industries. ${ }^{243}$ Little is known about the effect of nanoparticles on aquatic organisms. Young carp and sturgeon exhibited a faster rate of growth upon iron nanoparticle feeding. ${ }^{244} \mathrm{~A}$ nanoselenium-supplemented diet could improve the final weight, relative gain rate, antioxidant status, and the glutathione peroxidase activities and muscle selenium concentrations of crucian carp (Carassius auratus gibelio). Moreover, nanoselenium was found more effective than organic selenomethionine in increasing muscle selenium content. ${ }^{245}$ Further, the growth and performance of the fish which were experimented on were found higher at nanolevel delivery of these nutraceuticals. ${ }^{246}$ Direct use of silver nanoparticles in water to treat a fungal disease has been found toxic to young trout, ${ }^{247}$ but a water filter coated with silver nanoparticles prevented fungal infections in rainbow trout farmed indoors. ${ }^{248}$

For fish health in aquaculture, nanotechnological applications include antibacterial surfaces in the aquaculture system, nanodelivery of veterinary products in fish food using porous nanostructures, and nanosensors for detecting pathogens in the water. ${ }^{249,250}$ Nanopurified water could be used for irrigation and fish culture. ${ }^{251}$

Nanomaterials have shown great potential in a wide range of environmental applications due to the extremely small particle size, large surface area, and high reactivity. ${ }^{252}$ Nanoscale iron-manganese binary oxide was an effective sorbent for removal of arsenic (III) and arsenic (V) from both synthetic and actual field groundwater. ${ }^{253}$

Calcium-alginate polymer is an excellent choice as an entrapment medium as it is nontoxic and has little solubility in water. The use of nanoscale zero-valent iron (diameter 10-90 $\mathrm{nm}$ with an average value of $35 \mathrm{~nm}$ ) entrapped in calciumalginate beads showed great promise for aqueous arsenic treatment. ${ }^{254} \mathrm{~A}$ water-cleaning product for swimming pools and fishponds called "NanoCheck" (Altair Nanotechnologies, Reno, NV, USA) uses $40 \mathrm{~nm}$ particles of a lanthanum-based compound which absorbs phosphates from the water and prevents algae growth. ${ }^{255}$ Lanthanum oxide nanoparticles 
were utilized to scavenge phosphate from microbial growth media for the use of targeted nutrient starvation as an antimicrobial strategy. The effect was shown on Escherichia coli, Staphylococcus carnosus, Penicillium roqueforti, and Chlorella vulgaris. ${ }^{256}$ Nanotechnology can be used to clean ground water. The US company Argonide (Sanford, FL, USA) is using $2 \mathrm{~nm}$ diameter aluminium oxide nanofibers (NanoCeram) as a water purifier. Filters made from $2 \mathrm{~nm}$ diameter aluminium oxide nanofibers (NanoCeram) can remove viruses, bacteria, and protozoan cysts from water. Nanoscale iron oxide particles are extremely effective at binding and removing arsenic from groundwater.

Pretreatment of rare earth oxide nanoparticles with phosphate in a neutral $\mathrm{pH}$ environment prevented their biological transformation into urchin shaped structures and profibrogenic effects. ${ }^{257}$ Nanocochleates are unique lipidbased supramolecular assemblies composed of a negatively charged phospholipid and a divalent cation. Nanocochleates, $50 \mathrm{~nm}$ cylindrical (cigarlike) nanoparticles, can be used to deliver nutrients such as vitamins, lycopene, and omega fatty acids more efficiently to cells, without affecting the color or taste of food. ${ }^{258}$ Researchers have met with moderate success at developing nanoencapsulated vaccines against the bacterium Listonella anguillarum in Asian carp ${ }^{259}$ and white spot syndrome virus in shrimp. ${ }^{260}$

Nanoparticles have promise for improving protection of farmed fish against diseases caused by pathogens. Chitosan nanoparticles are promising carriers for an oral plasmid DNA vaccine. For example, oral administration with chitosan/ pDNA induced an antibody immune response in fish against Vibrio parahaemolyticus (OS4). ${ }^{261,262}$

\section{Particle farming}

Scientists have found a way to grow and harvest gold from crop plants. Nanoparticles could be industrially harvested. For example, alfalfa plants grown in an $\mathrm{AuCI}_{4}{ }^{-}$rich environment showed absorption of gold metal by the plants. The gold nanoparticles can be mechanically separated by dissolving the organic material (plant tissue) following harvest. ${ }^{263}$

Researchers reported the uptake of silver by living alfalfa plants from a silver-rich solid medium and the subsequent formation of silver nanoparticles. ${ }^{264}$ After immersing geranium leaves in a gold-rich solution for 3-4 hours, the leaves produced $10 \mathrm{~nm}$-sized particles shaped as rods, spheres, and pyramids. ${ }^{265}$ The husks containing natural silicon nanoparticles can easily be extracted and used in battery manufacture. ${ }^{266}$ Phytosynthesis of metal nanoparticles has been reported in plants. ${ }^{267}$

\section{Toxicology aspects, associated risks, and regulatory aspects}

In terms of global food and livestock production, the main aspects of nanotechnology are improved quality and nutritional value. In spite of potential benefits that nanotechnology offers in the agri-food sector (food production, feed for livestock, food ingredients, packaging, and nanobased smart systems), little is known on safety aspects of the application of nanotechnologies in food production and the incorporation of nanoparticles in food. Moreover, consumers still lack knowledge about nanotechnology.

Risk-assessment procedures are not specific to agri-food nano-materials, resulting in uncertainty regarding the nature and extent of potential risks in most cases. Applications for nanomaterials currently used for meat, and food generally, include the use of nanoparticles and nanomaterials as food ingredients/additives that are placed directly into food or as a part of food packaging. ${ }^{268}$ There is a need to pay attention to public views regarding new technologies in the food business during the product-development stage to avoid some of the pitfalls encountered by the genetically modified food industry. ${ }^{269}$ The release of engineered nanoparticles may cause adverse effects on edible plants. ${ }^{270}$ The potential risks and benefits of using nanosilver as an antibacterial agent in consumer and health care products are being debated globally. ${ }^{271}$

Elevated cerium content was detected in plant tissues exposed to cerium oxide nanoparticles, suggesting that cerium oxide nanoparticles were taken up by tomato roots and translocated to shoots and edible tissues. In particular, substantially higher cerium concentrations were detected in the fruits exposed to $10 \mathrm{mg} \mathrm{L}^{-1}$ cerium oxide nanoparticles, compared with controls. This study sheds light on the long-term impact of cerium oxide nanoparticles on plant health and its implications for our food safety and security. ${ }^{272}$ Lack of regulatory harmonization and empirical data are impeding global strategies for products commercializing nanotechnologies. ${ }^{273}$ Thus, there is an urgent need for regulatory systems capable of managing any risks associated with nanofoods and the use of nanotechnology in the food industry. ${ }^{274}$

In 2012 a new biocidal product regulation (EU 528/2012) was adopted in the European Union. The regulation specifically requires assessment and approval of active nanomaterial biocidal ingredients.

The environmental and societal implications of nanotechnology was assessed. ${ }^{275}$

The European Parliament Committee on the Environment, Public Health and Food Safety rejected a proposed regulation that would define "engineered nanomaterials" in food, on 
February 12, 2014. Such definition could lead to existing nanomaterials not being labeled due to an exemption provided for food additives approved on a European Union list. ${ }^{276,277}$

\section{Conclusion and perspective}

Many diverse opportunities for nanotechnology exist to play an important role in agriculture and food production as well as in livestock production. The potential uses and benefits of nanotechnology are enormous. Productivity enhancement through nanotechnology-driven precision farming and maximization of output and minimization of inputs through better monitoring and targeted action is desirable. Nanotechnology enables plants to use water, pesticides, and fertilizers more efficiently. Nanotechnology use may bring potential benefits to farmers through food production and to the food industry through development of innovative products through food processing, preservation, and packaging. Anticipated agri-food nanotechnology applications include nanosensors/nanobiosensors for detecting pathogens and for soil quality and for plant health monitoring, nanoporous zeolites for slow-release and efficient dosage of water and fertilizers for plants and of nutrients and drugs for livestock, nanocapsules for agrochemical delivery, creating biofuels, nanocomposites for plastic film coatings used in food packaging, antimicrobial nanoemulsions for applications in decontamination of food, nanobiosensors for identification of pathogen contamination, and improving plant and animal breeding.

Even so, less effort is going into applications of nanotechnology in agri-food sectors. Further, existing efforts are more oriented to reduce the negative impact of agrochemical products in the environment and human health, rather than the utilization of nanotechnology applications to improve their properties for food and livestock production.

Experts envision numerous nanoparticulate agroformulations with higher bioavailability and efficacy and better selectivity in the near future. Multidisciplinary approaches could potentially improve food production, incorporating new emerging technologies and disciplines such as chemical biology integrated with nanotechnologies to tackle existing biological bottlenecks that currently limit further developments. The potential benefits of nanotechnology for agriculture, food, fisheries, and aquaculture need to be balanced against concerns for the soil, water, environment, and the occupational health of workers.

\section{Disclosure}

The author reports no conflict of interest in this work.

\section{References}

1. Ghasemzadeh A. Global issues of food production. Agrotechnol. 2012;1:e102. doi:10.4172/2168-9881.1000e102

2. Brennan B. Nanobiotechnology in Agriculture. Menlo Park, CA: Strategic Business Insights; 2012; Available from: http://www. strategicbusinessinsights.com/about/featured/2012/2012-10-nanobioagriculture.shtml. Accessed April 18, 2014.

3. Batsmanova LM, Gonchar LM, Taran NY, Okanenko AA. Using a colloidal solution of metal nanoparticles as micronutrient fertiliser for cereals. Proceedings of the International Conference on Nanomaterials: Applications and Properties; September 16-21, 2013; Crimea, Ukraine. Available from: http://nap.sumdu.edu.ua/index.php/nap/nap2013/paper/ view/1097/504. Accessed April 18, 2014.

4. Scott N, Chen H, editors. Nanoscale science and engineering for agriculture and food systems. National Planning Workshop; November 18-19, 2002; Washington, DC. Available from: http:// www.nseafs.cornell.edu/web.roadmap.pdf. Accessed April 18, 2014.

5. Garcia M, Forbe T, Gonzalez E. Potential applications of nanotechnology in the agro-food sector. Food Science and Technology (Campinas). 2010;30(3):573-581.

6. Gruère G, Narrod C, Abbott L. Agriculture, Food, and Water Nanotechnologies for the Poor: Opportunities and Constraints. Policy Brief 19. Washington, DC: International Food Policy Research Institute; 2011. Available from http://www.ifpri.org/sites/default/files/ publications/bp019.pdf. Accessed May 6, 2014.

7. Frewer LJ, Norde W, Fischer ARH, Kampers FWH, editors. Nanotechnology in the Agri-Food Sector: Implications for the Future. Weinheim, Germany: Wiley-VCH; 2011.

8. Pérez-de-Luque A, Hermosín MC. Nanotechnology and its use in agriculture. In: Bagchi D, Bagchi M, Moriyama H, Shahidi F, editors. Bio-nanotechnology: A Revolution in Food, Bomedical and Health Sciences. Wiley-Blackwell, West Sussex, UK; 2013:299-405.

9. Prasad R, Kumar V, Prasad KS. Nanotechnology in sustainable agriculture: present concerns and future aspects. Afr J Biotechnol. 2014;13(6):705-713.

10. Biswal SK, Nayak AK, Parida UK, Nayak PL. Applications of nanotechnology in agriculture and food sciences. IJSID. 2012;2(1): 21-36.

11. Ditta A. How helpful is nanotechnology in agriculture? Advances in Natural Sciences: Nanoscience and Nanotechnology. 2012; 3(3):033002.

12. Sonkaria S, Ahn SH, Khare V. Nanotechnology and its impact on food and nutrition: a review. Recent Pat Food Nutr Agric. 2012;4(1):8-18.

13. Coles D, Frewer LJ. Nanotechnology applied to European food production: a review of ethical and regulatory issues. Trends Food Sci Technol. 2013;34(1):32-43.

14. Hong J, Peralta-Videa JR, Gardea-Torresdey J. Nanomaterials in agricultural production: benefits and possible threats? In: Shamim N, Sharma VK. Sustainable Nanotechnology and the Environment: Advances and Achievements. Washington, DC: American Chemical Society; 2013:73-90.

15. Raliya R, Tarafdar JC, Gulecha K, et al. Review article; scope of nanoscience and nanotechnology in agriculture. Journal of Applied Biology and Biotechnology. 2013;1(03):041-044.

16. Kuzma J, VerHage P. Nanotechnology in Agriculture and Food Production: Anticipated Applications. Washington, DC: The Project on Emerging Nanotechnologies; 2006. Available from: http://www. nanotechproject.org/process/assets/files/2706/94_pen4_agfood.pdf. Accessed May 6, 2014.

17. Cortes-Lobos R. Can Agri-Food Nanotechnology Contribute to Achieve the Millennium Development Goals in Developing Countries? Los Polvorines, Argentina: Universidad Nacional de General Sarmiento; 2011. Available from: http://www.ungs.edu.ar/globelics/wp-content/ uploads/2011/12/ID-15-Cortes-Learning-and-innovation-lessons-fromsectorial-studies.pdf. Accessed April 18, 2014. 
18. Chen H, Seiber JN, Hotze M. ACS select on nanotechnology in food and agriculture: A perspective on implications and applications. J Agri Food Chem. 2014;62(6):1209-1212.

19. Committee on Technology. National Nanotechnology Initiative: Strategic Plan. Washington, DC: National Science and Technology Council; 2014. Available from: http://nano.gov/sites/default/files/ pub_resource/2014_nni_strategic_plan.pdf. Accessed April 18, 2014.

20. The European Commission. Commission Recommendation of 18 October 2011 on the Definition of Nanomaterial. Brussels, Belgium Official Journal of the European Union; 2011. Available from: http:// eur-lex.europa.eu/LexUriServ/LexUriServ.do?uri=OJ:L:2011:275:003 8:0040:EN:PDF. Accessed April 18, 2014.

21. Stanley S. Biological nanoparticles and their influence on organisms. Curr Opin Biotechnol. 2014;28:69-74.

22. Zhang G, Zhang J, Xie G, Liu Z, Shao H. Cicada wings: a stamp from nature for nanoimprint lithography. Small. 2006;2(12):1440-1443.

23. Dewan R, Fischer S, Meyer-Rochow VB, ÖzdemirY, Hamraz S, Knipp D. Studying nanostructured nipple arrays of moth eye facets helps to design better thin film solar cells. Bioinspir Biomim. 2012;7(1):016003.

24. Peisker H, Gorb SN. Always on the bright side of life: antiadhesive properties of insect ommatidia grating. J Exp Biol. 2010; 213(Pt 20):3457-3462.

25. Tam HL, Cheah KW, Goh DTP, Goh JKL. Iridescence and nanostructure differences in Papilio butterflies. Optical Materials Express 2013;3(8):1087-1092.

26. Rensselaer Polytechnic Institute. Nanotube adhesive sticks better than a gecko's foot [webpage on the Internet]. ScienceDaily; 2007. Available from: http://www.sciencedaily.com/releases/2007/06/070619083554 htm. Accessed April 18, 2014.

27. Esquivel DMS. Magnetic nanoparticles in social insects: are they the geomagnetic sensors? Entomological Society of America 2007 Annual Meeting; December 9-12, 2007; San Diego, CA.

28. Thornton PK. Livestock production: recent trends, future prospects. Phil Trans R Soc B. 2010;365(1554):2853-2867.

29. Senturk A, Yalcin B, Otles S. Nanotechnology as a food perspective. J Nanomater Mol Nanotechnol. 2013;2:6

30. Boom RM. Nanotechnology in food production. In: Frewer LJ, Norde W, Fischer ARH, Kampers FWH, editors. Nanotechnology in the Agri-Food Sector: Implications for the Future. Weinheim, Germany: Wiley-VCH; 2011:39-58.

31. Zhao M, Liu L, Her R, et al. Nano-sized delivery for agricultural chemicals. In: Tiddy G, Tan R. NanoFormulation. Cambridge, UK: Royal Society of Chemistry; 2012:256-265.

32. Forsberg EM, de Lauwere C. Integration needs in assessments of nanotechnology in food and agriculture. Etikk i Praksis. 2013;1(1):38-54.

33. Scott NR. Nanotechnology opportunities in agriculture and food systems. Biological and Environmental Engineering, Cornell University NSF Nanoscale Science and Engineering Grantees Conference; December 5 , 2007; Arlington, VA. Available from: http://www.nseresearch.org/2007/ overviews/Day3_Scott.pdf. Accessed April 19, 2014.

34. Joseph T, Morrison M. Nanoforum Report: Nanotechnology in Agriculture and Food, European Nanotechnology Gateway; 2006. Available from: ftp://ftp.cordis.europa.eu/pub/nanotechnology/docs/ nanotechnology_in_agriculture_and_food.pdf. Accessed April 18, 2014.

35. Owolade OF, Ogunleti DO, Adenekan MO. Titanium dioxide affects diseases, development and yield of edible cowpea. EJEAFChe. 2008;7(5):2942-2947.

36. Knauer K, Bucheli TD. Nano-materials: research needs in agriculture. Revue Suisse d'Agriculture. 2009;41(6):337-341.

37. Manimegalai G, Kumar SS, Sharma C. Pesticide mineralization in water using silver nanoparticules. International Journal of Chemical Sciences. 2011;9(3):1463-1471.

38. Sasson Y, Levy-Ruso G, Toledano O, Ishaaya I. Nanosuspensions: emerging novel agrochemical formulations. In: Ishaaya I, Nauen R, Horowitz AR, editors. Insecticides Design Using Advanced Technologies. Springer-Verlag Berlin Heidelberg; 2007:1-39.
39. Perlatti B, de Souza Bergo PL, da Silva MF, et al. Polymeric nanoparticlebased insecticides: a controlled release purpose for agrochemicals, insecticides. In: Trdan S, editor. Insecticides: Development of Safer and More Effective Technologies. InTech; 2013:523-550.

40. Boehm AL, Martinon I, Zerrouk R, Rump E, Fessi H. Nanoprecipitation technique for the encapsulation of agrochemical active ingredients. J Microencapsul. 2003;20(4):433-441.

41. Elek N, Hoffman R, Raviv U, Resh R, Ishaaya I, Magdassi S. Novaluron nanoparticles: Formation and potential use in controlling agricultural insect pests. Colloids Surf A Physicochem Eng Asp. 2010;372(1-3):66-72.

42. Gogos A, Knauer K, Bucheli TD. Nanomaterials in plant protection and fertilization: current state, foreseen applications, and research priorities. J Agric Food Chem. 2012;60(39):9781-9792.

43. Adak T, Kumar J, Shakil NA, Walia S. Development of controlled release formulations of imidacloprid employing novel nano-ranged amphiphilic polymers. J Environ Sci Health B. 2012;47(3):217-225.

44. Adak T, Kumar J, Dey D, Shakil NA, Walia S. Residue and bio-efficacy evaluation of controlled release formulations of imidacloprid against pests in soybean (Glycine max). J Environ Sci Health B. 2012;47(3): 226-231.

45. Kumar J, Shakil NA, Khan MA, Malik K, Walia S. Development of controlled release formulations of carbofuran and imidacloprid and their bioefficacy evaluation against aphid, Aphis gossypii and leafhopper, Amrasca biguttula biguttula Ishida on potato crop. J Environ Sci Health B. 2011;46(8):678-682.

46. Al-Samarrai AM. Nanoparticles as alternative to pesticides in management plant diseases-a review. International Journal of Scientific and Research Publications. 2012;2(4):1-4.

47. Bhattacharyya A, Bhaumik A, Rani PU, Mandal S, Epidi TT. Nanoparticles - a recent approach to insect pest control. Afr J Biotechnol. 2010;9(24):3489-3493.

48. Vinutha JS, Bhagat D, Bakthavatsalam N. Nanotechnology in the management of polyphagous pest Helicoverpa armigera. J Acad Indus Res. 2013;1(10):606-608.

49. Jayaseelan C, Rahuman AA, Rajakumar G, et al. Synthesis of pediculocidal and larvicidal silver nanoparticles by leaf extract from heartleaf moonseed plant, Tinospora cordifolia Miers. Parasitol Res. 2011;109(1):185-194.

50. Vidyalakshmi R, Bhakyaraj R, Subhasree RS. Encapsulation "the future of probiotics" - A review. Adv Biol Res. 2009;3(3-4):96-103.

51. Yang FL, Li XG, Zhu F, Lei CL. Structural characterization of nanoparticles loaded with garlic essential oil and their insecticidal activity against Tribolium castaneum (Herbst) (Coleoptera: Tenebrionidae). J Agric Food Chem. 2009;57(21):10156-10162.

52. Barik TK, Sahu B, Swain V. Nanosilica-from medicine to pest control. Parasitol Res. 2008;103(2):253-258.

53. Hatschek E, inventor; Electro Chem. Processes, Ltd, assignee. Brouisol. British patent no 392,556. November 17, 1931.

54. Green JM, Beestman GB. Recently patented and commercialized formulation and adjuvant technology. Crop Protection. 2007;26(3):320-327.

55. Kah M, Beulke S, Tiede K, Hofmann T. Nanopesticides: state of knowledge, environmental fate, and exposure modeling. Crit Rev Environ Sci Technol. 2013;43(16):1823-1867.

56. Kumar R, Sharon M, Choudhary AK. Nanotechnology in agricultural diseases and food safety. Journal of Phytology. 2010;2(4):83-92.

57. Pérez-de-Luque A, Rubiales D. Nanotechnology for parasitic plant control. Pest Manag Sci. 2009;65(5):540-545.

58. Lamsal K, Kim SW, Jung JH, Kim YS, Kim KS, Lee YS. Inhibition effects of silver nanoparticles against powdery mildews on cucumber and pumpkin. Mycobiology. 2011;39(1):26-32.

59. Afrasiabi Z, Eivazi F, Popham H, Stanley D, Upendran A, Kannan R. Silver nanoparticles as pesticides. National Institute of Food and Agriculture 1890 Capacity Building Grants Program Project Director's Meeting; September 16-19, 2012; Huntsville, AL.

60. Rai M, Ingle A. Role of nanotechnology in agriculture with special reference to management of insect pests. Appl Microbiol Biotechnol. 2012;94(2):287-293. 
61. Goswami A, Roy I, Sengupta S, Debnath N. Novel applications of solid and liquid formulations of nanoparticles against insect pests and pathogens. Thin Solid Films. 2010;519(3):1252-1257.

62. Chakravarthy AK, Chandrashekharaiah, Kandakoor SB, et al. Bio efficacy of inorganic nanoparticles CdS, Nano-Ag and Nano-TiO2 against Spodoptera litura (Fabricius) (Lepidoptera: Noctuidae). Current Biotica. 2012;6(3):271-281.

63. Prasanna BM. Nanotechnology in Agriculture. New Delhi, India: Indian Agricultural Statistics Research Institute; 2007. Available from: http:// www.iasri.res.in/ebook/EBADAT/6-Other Useful Techniques/10nanotech_in_Agriculture_BM_Prasanna_1.2.2007.pdf. Accessed April 18, 2014.

64. Ulrichs C, Mewis I, Goswami A. Crop diversification aiming nutritional security in West Bengal: biotechnology of stinging capsules in nature's water-blooms. Ann Tech Issue of State Agri Technologists Service Assoc. 2005:1-18.

65. Cioffi N, Torsi L, Ditaranto N, et al. Antifungal activity of polymerbased copper nanocomposite coatings. Appl Phys Lett. 2004;85(12): 2417-2419.

66. Park HJ, Kim SH, Kim HJ, Choi SH. A new composition of nanosized silica-silver for control of various plant diseases. Plant Pathol J. 2006;22(3):295-302.

67. Jo YK, Kim BH, Jung G. Antifungal activity of silver ions and nanoparticles on phytopathogenic fungi. Plant Dis. 2009;93(10):1037-1043.

68. Esteban-Tejeda L, Malpartida F, Esteban-Cubillo A, Pecharromán C, Moya JS. Antibacterial and antifungal activity of a soda-lime glass containing copper nanoparticles. Nanotechnology. 2009;20(50):505701.

69. Guan H, Chi D, Yu J, Li X. A novel photodegradable insecticide: preparation, characterization and properties evaluation of nanoImidacloprid. Pestic Biochem Physiol. 2008;92(2):83-91.

70. Scrinis G, Lyons K. The emerging nano-corporate paradigm: nanotechnology and the transformation of nature, food and agri-food systems. International Journal of Sociology of Food and Agriculture. 2007;15(2):22-44.

71. Stadler T, Buteler M, Weaver DK. Novel use of nanostructured alumina as an insecticide. Pest Manag Sci. 2010;66(6):577-579.

72. Abdullayev E, Lvov Y. Halloysite clay nanotubes for controlled release of protective agents. J Nanosci Nanotechnol. 2011;11(11): $10007-10026$

73. Murphy K, editor. Nanotechnology: Agriculture's Next "Industrial" Revolution. Williston, VT: Financial Partner, Yankee Farm Credit, ACA; Spring, 2008:3-5.

74. Lodriche SS, Soltani S, Mirzazadeh R, inventors and assignees. Silicon nanocarrier for delivery of drug, pesticides and herbicides, and for waste water treatment. United States patent US 20130225412 A1. August 29, 2013.

75. Sarijo SH, bin Hussein MZ, Yahaya AH, Zainal Z, Yarmo MA. Synthesis of phenoxyherbicides-intercalated layered double hydroxide nanohybrids and their controlled release property. Curr Nanosci. 2010;6(2):199-205.

76. Hussein MZ, Hashim N, Yahaya AH, Zainal Z. Synthesis and characterization of [4-(2,4-dichlorophenoxybutyrate)-zinc layered hydroxide] nanohybrid. Solid State Sciences. 2010;12(5):770-775.

77. Hussein MZ, Rahman NS, Sarijo SH, Zainal Z. Herbicide-intercalated zinc layered hydroxide nanohybrid for a dual-guest controlled release formulation. Int J Mol Sci. 2012;13(6):7328-7342.

78. Bashi AM, Haddawi SM, Dawood AH. Synthesis and characterizations of two herbicides with $\mathrm{Zn} / \mathrm{Al}$ layered double hydroxide nano hybrides. Journal of Kerbala University. 2011;9(1):9-16.

79. Hussein MZ, Sarijo SH, Yahaya AH, Zainal Z. Synthesis of 4-chlorophenoxyacetate-zinc-aluminium-layered double hydroxide nanocomposite: physico-chemical and controlled release properties. J Nanosci Nanotechnol. 2007;7(8):2852-2862.

80. Hussein MZ, Yahya AH, Zainal Z, Kian LH. Nanocomposite-based controlled release formulation of herbicide 2,4-dichlorophenoxy acetate encapsulated in $\mathrm{Zn} / \mathrm{Al}$ layered double hydroxide. Sci Tech Adv Mater. 2005;6(8):956-962.
81. Sheikh Mohd Ghazali SAI, Hussein MZ, Sarijo SH. 3,4-Dichlorophenoxyacetate interleaved into anionic clay for controlled release formulation of a new environmentally friendly agrochemical. Nanoscale Res Lett. 2013;8(1):362.

82. Kanimozhi V, Chinnamuthu CR. Engineering core/hallow shell nanomaterials to load herbicide active ingredient for controlled release. Research Journal of Nanoscience and Nanotechnology. 2012;2(2): $58-69$.

83. Lai F, Wissing SA, Mller RH, Fadda AM. Artemisia arborescens L. essential oil loaded, solid lipid nanoparticles for potential agricultural application: Preparation and characterization. AAPS Pharm Sci Tech. 2006;7:1-2.

84. Lai F, Wissing SA, Müller RH, Fadda AM. Artemisia arborescens L essential oil-loaded solid lipid nanoparticles for potential agricultural application: preparation and characterization. AAPS PharmSciTech. 2006;7(1):E2.

85. Sastry RK, Rao NH, Cahoon R, Tucker T. Can nanotechnology provide the innovations for a second green revolution in Indian agriculture? NSF Nanoscale Science and Engineering Grantees Conference; December 3-6, 2007; Arlington, VA.

86. Gajbhiye M, Kesharwani J, Ingle A, Gade A, Rai M. Fungus-mediated synthesis of silver nanoparticles and their activity against pathogenic fungi in combination with fluconazole. Nanomedicine. 2009;5(4): 382-386.

87. Vinutha JS, Deepa Bhagat D, Bakthavatsalam N. Nanotechnology in the management of polyphagous pest Helicoverpa armigera. J Acad Indus Res. 2013;1(10):606-608.

88. Fulekar MH. Nanotechnology in agriculture and food industry. In: Fulekar MH. Nanotechnology: Importance and Applications. New Delhi, India: I. K. International Publishing House Pvt Ltd; 2010:139-157.

89. Soni N, Prakash S. Efficacy of fungus mediated silver and gold nanoparticles against Aedes aegypti larvae. Parasitol Res. 2012;110(1): 175-184.

90. Rao KJ, Paria S. Use of sulfur nanoparticles as a green pesticide on Fusarium solani and Venturia inaequalis phytopathogens. RSC Advances. 2013;3(26):10471-10478.

91. Bhagat D, Samanta SK, Bhattacharya S. Efficient management of fruit pests by pheromone nanogels. Sci Rep. 2013;3:1294.

92. Stadler T, Buteler M, Weaver DK, Sofie S. Comparative toxicity of nanostructured alumina and a commercial inert dust for Sitophilus oryzae (L.) and Rhyzopertha dominica (F.) at varying ambient humidity levels. J Stored Product Res. 2012;48:81-90.

93. Rosenthal JA, Chen L, Baker JL, Putnam D, DeLisa MP. Pathogen-like particles: biomimetic vaccine carriers engineered at the nanoscale. Curr Opin Biotechnol. 2014;28:51-58.

94. Ghormade V, Deshpande MV, Paknikar KM. Perspectives for nanobiotechnology enabled protection and nutrition of plants. Biotechnol Adv. 2011;29(6):792-803.

95. Haghighi M, Pourkhaloee A. Nanoparticles in agricultural soils: their risks and benefits for seed germination. Minerva Biotecnol. 2013;25(2):123-132.

96. Naderi MR, Abedi A. Application of nanotechnology in agriculture and refinement of environmental pollutants. J Nanotechnol. 2012;11(1):18-26. [In Persian with English Summary]. http:// jm.birjand.ac.ir/archive_jou/escs/139261/4P-ESCS61-A91216.pdf. Accessed May 6, 2014.

97. Moaveni P, Kheiri T. TiO2 nano particles affected on maize (Zea mays L). 2nd International Conference on Agricultural and Animal Science; November 25-27, 2011; Maldives. Singapore: IACSIT Press; 2011;22:160-163.

98. Lu CM, Zhang CY, Wen JQ, Wu GR, Tao MX. Research of the effect of nanometer materials on germination and growth enhancement of glycine max and its mechanism. Soybean Science. 2002;21(3): 168-171.

99. Iran Nanotechnology Initiative Council. First nano-organic iron chelated fertilizer invented in Iran [webpage on the Internet]. Tehran, Iran: Iran Nanotechnology Initiative Council; 2009. Available from: http://www.iranreview.org/content/Documents/Iranians_Researchers_ Produce_Nano_Organic_Fertilizer.htm. Accessed April 11, 2014. 
100. Naderi MR, Danesh-Shahraki A. Nanofertilizers and their roles in sustainable agriculture. Int J Agri Crop Sci. 2013;5(19):2229-2232.

101. Panwar J, Jain N, Bhargaya A, Akhtar MS, Yun YS. Positive effect of zinc oxide nanoparticels on tomato plants: A step towards developing "Nano-fertilizers" 01/2012; Proceeding of 3rd International Conference on Environmental Research and Technology (ICERT); May 30-June 1, 2012; Penang, Malaysia.

102. de la Rosa G, Lopez-Moreno ML, De Haro D, Botez CE; Peralta-Videa, JR, Gardea-Torresdey J. Effects of $\mathrm{ZnO}$ nanoparticles in alfalfa, tomato, and cucumber at the germination stage: root development and X-ray absorption spectroscopy studies Pure Appl. Chem. 2013; 85(12):2161-2174.

103. DeRosa MC, Monreal C, Schnitzer M, Walsh R, Sultan Y. Nanotechnology in fertilizers. Nat Nanotechnol. 2010;5(2):91.

104. Liu X, Feng Z, Zhang S, Zhang J, Xiao Q, Wang Y. Preparation and testing of cementing nano-subnano composites of slow or controlled release of fertilizers. Sci Agr Sin. 2006;39:1598-1604. Available from: http://en.cnki.com.cn/Article_en/CJFDTOTAL-ZNYK200608011. htm. Accessed April 19, 2014.

105. Guo J. Synchrotron radiation, soft X-ray spectroscopy and nanomaterials. Int J Nanotecccessedhnol. 2004;1(1):193-225.

106. Kottegoda N, Munaweera I, Madusanka N, Karunaratne V. A green slowrelease fertilizer composition based on urea-modified hydroxyapatite nanoparticles encapsulated wood. Curr Sci. 2011;101(1):73-78.

107. Manikandan A, Subramanian KS. Fabrication and characterisation of nanoporous zeolite based N fertilizer. Afr J Agric Res. 2014;9(2): 276-284.

108. Khodakovskaya M, Dervishi E, Mahmood, M, et al. Carbon nanotubes are able to penetrate plant seed coat and dramatically affect seed germination and plant growth. ACS Nano. 2009;3(10): 3221-3227.

109. Rai V, Acharya S, Dey N. Implications of nanobiosensors in agriculture. J Biomater Nanobiotchnol. 2012;3:315-324.

110. El-Ramady HR. Integrated Nutrient Management and Postharvest of Crops. Sustainable Agri Rev. 2014;13:163-274.

111. Sastry RK, Rao NH. Emerging technologies for enhancing Indian agriculture-case of nanobiotechnology. Asian Biotechnology and Development Review. 2013;15(1):1-9.

112. AZoNano.com. Nanofibers to be used in drug delivery, gene therapy, crop engineering and environmental monitoring [webpage on the Internet]. Manchester, UK: AZoM.com Pty. Ltd; 2003 [updated June 11, 2013]. Available from: http://www.azonano.com/article. aspx?ArticleID=114. Accessed April 19, 2014.

113. Torney F, Trewyn BG, Lin VS, Wang K. Mesoporous silica nanoparticles deliver DNA and chemicals into plants. Nat Nanotechnol. 2007;2(5):295-300

114. ETC Group. Extreme Genetic Engineering: An Introduction to Synthetic Biology. Ottawa, Canada: Action Group on Erosion, Technology and Concentration; 2007. Available from: http://www.etcgroup.org/ sites/www.etcgroup.org/files/report/etcannual-report0607_sm.pdf Accessed April 19, 2014.

115. Kuzma J. Moving forward responsibly: oversight for the nanotechnologybiology interface. J Nanopart Res. 2007;9:165-182.

116. Maysinger D. Nanoparticles and cells: good companions and doomed partnerships. Org Biomol Chem. 2007;5(15):2335-2342.

117. Kole C, Kole P, Randunu KM, et al. Nanobiotechnology can boost crop production and quality: first evidence from increased plant biomass, fruit yield and phytomedicine content in bitter melon (Momordica charantia). BMC Biotechnol. 2013;13:37.

118. Zheng J, Birktoft JJ, Chen Y, et al. From molecular to macroscopic via the rational design of a self-assembled 3D DNA crystal. Nature. 2009;461(7260):74-77.

119. Kovalchuk I, Ziemienowicz A, Eudes F, inventors; Plantbiosis Ltd, assignee. T-DNA/protein nano-complexes for plant transformation. United States patent US 20120070900 A1. March 22, 2012.

120. Park IY, Kim IY, Yoo MK, Choi YJ, Cho MH, Cho CS. Mannosylated polyethylenimine coupled mesoporous silica nanoparticles for receptormediated gene delivery. Int J Pharm. 2008;359(1-2):280-287.
121. Galbraith DW. Nanobiotechnology: silica breaks through in plants. Nat Nanotechnol. 2007;2(5):272-273.

122. Jones PBC. A Nanotech Revolution in Agriculture and the Food Industry. Blacksburg, VA: Information Systems for Biotechnology; 2006. Available from: http://www.isb.vt.edu/articles/jun0605.htm. Accessed April 19, 2014.

123. Brock DA, Douglas TE, Queller DC, Strassmann JE. Primitive agriculture in a social amoeba. Nature. 2011;469(7330):393-396.

124. Mousavi SR, Rezaei M. Nanotechnology in agriculture and food production. J Appl Environ Biol Sci. 2011;1(10):414-419.

125. Li Y, Cu YT, Luo D. Multiplexed detection of pathogen DNA with DNA-based fluorescence nanobarcodes. Nat Biotechnol. 2005;23(7): 885-889.

126. McLamore ES, Diggs A, Calvo Marzal P, et al. Non-invasive quantification of endogenous root auxin transport using an integrated flux microsensor technique. Plant J. 2010;63(6):1004-1016.

127. da Silva AC, Deda DK, da Róz AL, et al. Nanobiosensors based on chemically modified AFM probes: a useful tool for metsulfuron-methyl detection. Sensors (Basel). 2013;13(2):1477-1489.

128. Otles S, Yalcin B. Nano-biosensors as new tool for detection of food quality and safety. LogForum. 2010;6(4):67-70.

129. Su HC, Zhang M, Bosze W, Lim JH, Myung NV. Metal nanoparticles and DNA co-functionalized single-walled carbon nanotube gas sensors. Nanotechnology. 2013;24(50):505502.

130. Farrell D, Hoover M, Chen H, Friedersdorf L. Overview of Resources And Support for Nanotechnology for Sensors and Sensors for Nanotechnology: Improving and Protecting Health, Safety, and the Environment. Arlington VA: US National Nanotechnology Initiative; 2013. Available from: http://nano.gov/sites/default/files/pub_resource/ nsi_nanosensors_resources_for_web.pdf. Accessed April 19, 2014.

131. Wanekaya AK, Chen W, Myung NV, Mulchandani A. Nanowire-based electrochemical biosensors. Electroanalysis. 2006;18(6):533-550.

132. Accenture Technology Labs. Remote Sensor Network: Accenture Prototype Helps Pickberry Vineyard Improve Crop Management. New York, NY: Accenture; 2004. Available from: http://www.accenture.com/SiteCollectionDocuments/PDF/pickberry.pdf. Accessed April 19, 2014.

133. Yotova L, Yaneva S, Marinkova D. Biomimetic nanosensors for determination of toxic compounds in food and agricultural products (review). Journal of Chemical Technology and Metallurgy. 2013;48(3): 215-227.

134. Majidi MR, Baj RFB, Naseri A. Carbon nanotube-ionic liquid (CNT-IL) nanocamposite modified sol-gel derived carbon-ceramic electrode for simultaneous determination of sunset yellow and tartrazine in food samples. Food Anal Methods. 2013;6(5):1388-1397.

135. Mura S, Seddaiu G, Bacchini F, Roggero PP, Greppi GF. Advances of nanotechnology in agro-environmental studies. Italian Journal of Agronomy. 2013;8(3):e18.

136. Pardha-Saradhi P, Yamal G, Peddisetty T, et al. Plants fabricate Fenanocomplexes at root surface to counter and phytostabilize excess ionic Fe. Biometals. 2014;27(1):97-114

137. Manceau A, Nagy KL, Marcus MA, et al. Formation of metallic copper nanoparticles at the soil-root interface. Environ Sci Technol. 2008;42(5):1766-1772.

138. Lu Q, Rosen J, Zhou Y, et al. A selective and efficient electrocatalyst for carbon dioxide reduction. Nat Commun. 2014;5:3242.

139. Xia L, Lenaghan SC, Zhang M, Zhang Z, Li Q. Naturally occurring nanoparticles from English ivy: an alternative to metal-based nanoparticles for UV protection. J Nanobiotechnology. 2010;8:12.

140. Burris JN, Lenaghan SC, Zhang M, Stewart CN. Nanoparticle biofabrication using English ivy (Hedera helix). J Nanobiotechnology. 2012;10:41.

141. Xia L, Lenaghan SC, Zhang M, et al. Characterization of English ivy (Hedera helix) adhesion force and imaging using atomic force microscopy. J Nanopart Res. 2011;13(3):1029-1037.

142. Lenaghan S, Zhang M. Real-time observation of the secretion of a nanocomposite adhesive from English ivy (Hedera helix). Plant Sci. 2012;183:206-211. 
143. Thul ST, Sarangi BK, Pandey RA. Nanotechnology in Agroecosystem: Implications on Plant Productivity and its Soil Environment. Expert Opinion on Environmental Biology. 2013;2:1.

144. Chauhan RPS, Gupta C, Prakash D. Methodological advancements in green nanotechnology and their applications in biological synthesis of herbal nanoparticles. International Journal of Bioassays. 2012;1(7):6-10.

145. Ajayan PM, Schadler LS, Braun PV, editors. Nanocomposite Science and Technology. Weinheim, Germany: Wiley-VCH Verlag GmbH and Co, KGaA; 2003.

146. Kumar SK, Krishnamoorti R. Nanocomposites: structure, phase behavior, and properties. Annu Rev Chem Biomol Eng. 2010;1:37-58.

147. KeYC, Stroeve P. Polymer-Layered Silicate and Silica Nanocomposites. 1st ed. Amsterdam, The Netherlands: Elsevier BV; 2005.

148. Chaudhry Q, Castle L, Watkins R, editors. Nanotechnologies in Food. Cambridge, UK: Royal Society of Chemistry, 2010.

149. Cao X, Habibi Y, Magalhães WLE, Rojas OJ, Lucia LA. Cellulose nanocrystals-based nanocomposites: fruits of a novel biomass research and teaching platform. Curr Sci. 2011;100(8):1172-1176.

150. Tiwari A, editor. Recent Developments in Bio-Nanocomposites for Biomedical Applications. 1st ed. Hauppauge, NY: Nova Science Publishers, Inc.; 2010.

151. Sozer N, Kokini JL. Nanotechnology and its applications in the food sector. Trends biotechnol. 2009;27(2):82-89.

152. Cortes-Lobos R. Nanotechnology research in the US agri-food sectoral system of innovation: towards sustainable development [dissertation]. Atlanta, GA: Georgia Institute of Technology; 2013.

153. Jatav GK, Mukhopadhyay R, De N. Characterization of swelling behavior of anoclay composite. International Journal of Innovative Research in Science, Engineering and Technology. 2013;2(5):1560-1563.

154. Ray SS. Environmentally Friendly Polymer Nanocomposites: Types, Processing and Properties. Cambridge, UK: Woodhead Publishing; 2013.

155. Kabiri K, Omidian H, Zohuriaan-Mehr MJ, Doroudiani S. Superabsorbent hydrogel composites and nanocomposites: a review. Polymer Composites. 2011;32(2):277-289.

156. Cao XD, Chen Y, Chang PR, Muir AD, Falk G. Starch-based nanocomposites reinforced with flax cellulose nanocrystals. Express Polym Lett. 2008;2(7):502-510.

157. Pandey S, Zaidib MGH, Gururani SK. Recent developments in claypolymer nano composites. Scientific Journal of Review. 2013;2(11): 296-328.

158. Peterson SC, Jackson MA, Appell M. Biochar: sustainable and versatile. In: Park B, Appell M, editors. Advances in Applied Nanotechnology for Agriculture. Washington, DC: American Chemical Society; 2013:193-205.

159. Joseph S, Graber ER, Chia C, et al. Shifting paradigms: development of high-efficiency biochar fertilizers based on nano-structures and soluble components. Carbon Management. 2013;4(3): 323-343.

160. Pignatello JJ, White JC, Uchimiya M. Nanoscale interactions between engineered nanomaterials and black carbon (biochar) in soil. 2013 NSF Nanoscale Science and Engineering Grantees Conference; December 4-6, 2013; Arlington, VA.

161. Espitia PJ, Soares Nde F, Teófilo RF, et al. Physical-mechanical and antimicrobial properties of nanocomposite films with pediocin and ZnO nanoparticles. Carbohydr Polym. 2013;94(1):199-208.

162. Ramsurn H, Gupta RB. Nanotechnology in solar and biofuels. ACS Sustainable Chem Eng. 2013;1(7):779-797.

163. Kumar A, Negi YS, Choudhary V, Bhardwaj NK. Characterization of cellulose nanocrystals produced by acid-hydrolysis from sugarcane bagasse as agro-waste. Journal of Materials Physics and Chemistry. 2014;2(1):1-8

164. Zhang XL, S. Tyagi YRD, Surampalli RY. Biodiesel production from heterotrophic microalgae through transesterification and nanotechnology application in the production. Renewable and Sustainable Energy Reviews. 2013;26:216-223.
165. Trindade SC. Nanotech biofuels and fuel additives. In: dos Santos Bernardes MA, editor. Biofuel's Engineering Process Technology. Rijeka, Croatia: InTech; 2011;103-114.

166. Valenstein JS. Developing Nanotechnology for Biofuel and Plant Science Applications [doctoral thesis]. Ames, IA: Iowa State University; 2012. Available from: http://lib.dr.iastate.edu/etd/12493. Accessed April 19, 2014.

167. Seaman C, Bricklebank N. Soil-free farming. Chemistry and Industry Magazine. 2011;19-21. Available from: http://www.soci. org/Chemistry-and-Industry/CnI-Data/2011/6/Soil-free-farming. Accessed April 19, 2014.

168. Giordani T, Fabrizi A, Guidi L, et al. Response of tomato plants exposed to treatment with nanoparticles. Environmental Quality. 2012;8(2012):27-38.

169. Schwabe F, Schulin R, Limbach LK, Stark W, Bürge D, Nowack B. Influence of two types of organic matter on interaction of $\mathrm{CeO} 2$ nanoparticles with plants in hydroponic culture. Chemosphere. 2013;91(4):512-520.

170. Dimkpa CO, McLean JE, Martineau N, Britt DW, Haverkamp R, Anderson AJ. Silver nanoparticles disrupt wheat (Triticum aestivum L.) growth in a sand matrix. Environ Sci Technol. 2013;47(2): 1082-1090.

171. Seaman C, Bricklebank N. Soil-free Farming, Chemistry and Engineering Magazine. 2011;6. Available from: http://www.soci.org/ Chemistry-and-Industry/CnI-Data/2011/6/Soil-free-farming. Accessed April 19, 2014.

172. Wipro Insights [webpage on the Internet]. Green nanotechnology: Making way for a sustainable future. Bangalore, India: Wipro Limited; 2012. Available from: http:/www.wipro.com/blog/Green-nanotechnologyMaking-way-for-a-sustainable-future. Accessed April 19, 2014.

173. Witanachchi S, Merlak M, Mahawela P. Nanotechnology solutions to greenhouse and urban agriculture. Technol Innov. 2012;14(2): 209-217.

174. IFOAM World Board. The use of Nanotechnologies and Nanomaterials in Organic Agriculture. Bonn, Germany: IFOAM World Board; 2011. Available from: http://www.ifoam.org/pt/ifoam-position-paper-usenanotechnologies-and-nanomaterials-organic-agriculture. Accessed April 19, 2014.

175. The Organic and Non-GMO Report [webpage on the Internet]. US organic standards board to ban nanotechnology from organic food. Fairfield, IA: The Organic and Non-GMO Report; 2009. Available from: http://www.non-gmoreport.com/articles/oct09/us_organic_ standards_ban_nanotechnology.php\#sthash.y2BGmFJB.dpuf. Accessed April 19, 2014.

176. The Organic and Non-GMO Report [webpage on the Internet]. Canada bans nanotechnology in organics. Fairfield, IA: The Organic and Non-GMO Report; 2010. Available from: http://www. non-gmoreport.com/articles/may10/canada_bans_nanotechnology_ organics.php\#sthash.a9TkE5CG.dpuf. Accessed April 19, 2014.

177. Raliya R, Tarafdar JC. ZnO nanoparticle biosynthesis and its effect on phosphorous-mobilizing enzyme secretion and gum contents in Clusterbean (Cyamopsis tetragonoloba L). Agricultural Research. 2013;2(1):48-57.

178. Nair R, Varghese SH, Nair BG, Maekawa T, Yoshida Y, Kumar DS. Nanoparticulate material delivery to plants. Plant Science. 2010;179(3): 154-163.

179. Rico CM, Majumdar S, Duarte-Gardea M, Peralta-Videa JR, GardeaTorresdey JL. Interaction of nanoparticles with edible plants and their possible implications in the food chain. J Agric Food Chem. 2011;59(8):3485-3498.

180. Agrawal S, Rathore P. Nanotechnology pros and cons to agriculture: A review. Int J Curr Microbiol App Sci. 2014;3(3):43-55.

181. Zheng L, Hong F, Lu S, Liu C. Effect of nano-TiO(2) on strength of naturally aged seeds and growth of spinach. Biol Trace Elem Res. 2005;104(1):83-92. 
182. Gao F, Hong F, Liu C, et al. Mechanism of nano-anatase TiO2 on promoting photosynthetic carbon reaction of spinach. Biol Trace Elem Res. 2006;111(1-3):239-253.

183. Yang F, Liu C, Gao F, et al. The improvement of spinach growth by nano-anatase $\mathrm{TiO} 2$ treatment is related to nitrogen photoreduction. Biol Trace Elem Res. 2007;119(1):77-88.

184. Linglan M, Chao L, Chunxiang Q, et al. Rubisco activase mRNA expression in spinach: modulation by nanoanatase treatment. Biol Trace Elem Res. 2008;122(2):168-178.

185. Liu XM, Zhang FD, Feng ZB, et al. Effects of nano-ferric oxide on the growth and nutrients absorption of peanut. Journal of Plant Nutrition and Fertilizer Science. 2010;11(4):551.

186. Giraldo JP, Landry MP, Faltermeier SM, et al. Plant nanobionics approach to augment photosynthesis and biochemical sensing. Nat Mater. 2014;13(4):400-408.

187. Ahmed F, Arshi N, Kumar S, et al. Chatper 11: Nanobiotechnology: scope and potential for crop improvement. In: Crop Improvement under Adverse Conditions. New York, NY: Springer; 2013 : 245-269.

188. Lei Z, Mingyu S, Xiao W, et al. Antioxidant stress is promoted by nano-anatase in spinach chloroplasts under UV-B radiation. Biol Trace Elem Res. 2008;121:69-79.

189. Lin S, Reppert J, Hu Q, et al. Uptake, translocation, and transmission of carbon nanomaterials in rice plants. Small. 2009;5(10): 1128-1132.

190. Khodakovskaya M, de Silva K, Nedosekin DA, et al. Complex genetic, photothermal, and photoacoustic analysis of nanoparticle-plant interactions. Proc Natl Acad Sci U S A. 2011;108(3):1028-1033.

191. Khodakovskaya MV, de Silva K, Biris AS, Dervishi E, Villagarcia H. Carbon nanotubes induce growth enhancement of tobacco cells. ACS Nano. 2012;6(3):2128-2135.

192. Sheykhbaglou R, Sedghi M, Shishevan MT, Sharifi RS. Effects of nano-iron oxide particles on agronomic traits of soybean. Notulae Scientia Biologicae. 2010;2(2):112-113.

193. Răcuciu M, Miclăuş S, Creangă DE. The response of plant tissues to magnetic fluid and electromagnetic exposure. Romanian Journal of Biophysics. 2009;19:73-82.

194. Răcuciu M, Creangă DE. TMA-OH coated magnetic nanoparticles internalized in vegetal tissue. Romanian Journal of Physics 2006;52(3-4):395-402.

195. Wang H, Kou X, Pei Z, Xiao JQ, Shan X, Xing B. Physiological effects of magnetite (Fe3O4) nanoparticles on perennial ryegrass (Lolium perenne L.) and pumpkin (Cucurbita mixta) plants. Nanotoxicology. 2011;5(1):30-42.

196. Mahmood T, Hussain ST. Nanobiotechnology for the production of biofuels from spent tea. African Journal of Biotechnology. 2010;9(6): 858-868.

197. Abid MF, Al-Naseri SK, Abdullah SN. Reuse of Iraqi agricultural drainage water using nanofiltration. J Membrane Separation Technol. 2013;2:53-62.

198. Hoek EMV, Ghosh AK. Chapter 4: Nanotechnology-based membranes for water purification. In: Savage N, Diallo M, Duncan J, Street A, Sustich R, editors. Nanotechnology Applications for Clean Water. Norwich, NY: William Andrew Inc.; 2009:47.

199. ScienceDaily ${ }^{\circledR}$ [webpage on the Internet]. Nanotechnology for water purification. Rockville, MD: ScienceDaily, LLC; 2010. Available from: http://www.sciencedaily.com/releases/2010/07/100728111711. htm. Accessed April 19, 2014.

200. Yavuz CT, Mayo JT, Yu WW, et al. Low-field magnetic separation of monodisperse Fe3O4 nanocrystals. Science. 2006;314(5801): 964-967.

201. Cohen-Tanugi D, Grossman JC. Water desalination across nanoporous graphene. Nano Lett. 2012;12(7):3602-3608.

202. Nanowerk [webpage on the Internet]. Researchers test nanofiltration solar desalination system for arid land agriculture. Honolulu, HI: Nanowerk; 2012. Available from: http:/www.nanowerk.com/news/ newsid=25380.php\#ixzz2t6GMqdkj. Accessed April 19, 2014.
203. Castricum HL, Sah A, Kreiter R, Blank DH, Vente JF, ten Elshof JE. Hybrid ceramic nanosieves: stabilizing nanopores with organic links. Chem Commun (Camb). 2008;(9):1103-1105.

204. Nanowerk [webpage on the Internet]. Food nanotechnology. Honolulu, HI: Nanowerk; 2014. Available from: http://www.nanowerk.com/ nanotechnology-in-food.php\#ixzz2rx2SfZwv. Accessed April 19, 2014

205. Nano Food 2040. Nanotechnology in Food, Foodprocessing, Agriculture, Packaging and Consumption State of Science, Technologies, Markets, Applications and Developments to 2015 and 2040. Available from: http://www.hkc22.com/nanofood2040.html. Accessed April 19, 2014.

206. The Project on Emerging Nanotechnologies [webpage on the Internet]. Consumer products inventory. Washington, DC: The Project on Emerging Nanotechnologies; 2013. Available from: http://www. nanotechproject.org/cpi. Accessed April 19, 2014.

207. Qureshi MA, Karthikeyan S, Punita K, Khan PA, Uprit S, Mishra UK. Application of nanotechnology in food and dairy processing: an overview. Pakistan Journal of Food Sciences. 2012;22(1):23-31.

208. Nanowerk [webpage on the Internet]. Nanotechnology products and applications. Product: GuardIN Fresh. Honolulu, HI; Nanowerk; 2014. Available from: http://www.nanowerk.com/products/product. php?id=119. Accessed April 19, 2014.

209. Nanowerk [webpage on the Internet]. Nanotechnology products and applications. Product: TopScreen DS13. Honolulu, HI: Nanowerk; 2014. Available from: http://www.nanowerk.com/products/product. php?id=30. Accessed April 19, 2014.

210. Nanowerk [webpage on the Internet]. Nanotechnology products and applications. Product: NanoCeram-PAC. Honolulu, HI: Nanowerk; 2014. Available from: http://www.nanowerk.com/products/product php?id=142. Accessed April 19, 2014.

211. Huang Q, editor. Nanotechnology in the Food, Beverage and Nutraceutical Industries. Cambridge, UK: Woodhead Publishing Limited; 2012.

212. Sharma TK, Sapra M, Chopra A, et al. Interaction of bacteriocin-capped silver nanoparticles with food pathogens and their antibacterial effect. International Journal of Green Nanotechnology. 2012;4(2):93-110.

213. OilFresh Corporation [homepage on the Internet]. OilFresh ${ }^{\circledR}$. Sunnyvale, CA: OilFresh Corporation; 2014. Available from: http:// www.oilfresh.com. Accessed April 19, 2014.

214. OilFresh Corporation. Press Release. Sunnyvale, CA: OilFresh Corporation; 2008. Available from: http://www.oilfresh.com/pdf/ OilFresh_WingZone\%2020080513\%20Final.pdf. Accessed April 19, 2014.

215. Lan T. Nanocomposites for food packaging: An overview. In: Bagchi M, Moriyama H, Shahidi F, editors. Bio-Nanotechnology: A Revolution in Food, Biomedical and Health Sciences, John Wiley \& Sons, 2012, pp 406-413.

216. Silvestre C, Duraccio D, Cimmino S. Food packaging based on polymer nanomaterials. Prog Polym Sci. 2011;36(12):1766-1782.

217. Guma-Diaz M [webpage on the Internet]. Tiny gold particles help researchers find protein impostor. Coral Gables, FL: University of Maimi; 2010. Available from: http://www.miami.edu/index.php/ news/releases/tiny_gold_particles_help_researchers_find_protein_ impostor_/. Accessed April 19, 2014.

218. Wei F, Lam R, Cheng S, Lu S, Ho D, Li N. Rapid detection of melamine in whole milk mediated by unmodified gold nanoparticles. App Phys Lett. 2010;96(13):133702.

219. Brody AL, Bugusu B, Han JH, Sand CK, McHugh TH. Scientific status summary. Innovative food packaging solutions. J Food Sci. 2008;73(8):R107-R116.

220. Chaudhry Q, Castle L. Food applications of nanotechnologies: An overview of opportunities and challenges for developing countries. Trends Food Sci Technol. 2011;22(11):595-603.

221. Langley $\mathrm{J}$ [webpage on the Internet]. Amid food scares, Nanotech offers healthier option for livestock. New York, NY: Popular Mechanics, Hearst Communication, Inc.; 2009. Available from: http://www.popularmechanics.com/science/research/4270075.html. Accessed April 19, 2014. 
222. Tzeng $\mathrm{J}$ [webpage on the Internet]. Intelligent chicken feed. Clemson, SC: Public Service Activities; 2014. Available from: http://www. clemson.edu/public/psatv/ag/intelligent_chicken_feed.html. Accessed April 19, 2014.

223. Davis D, Guo X, Musavi L, Lin CS, Chen SH, Wu VCH. Gold nanoparticle-modified carbon electrode biosensor for the detection of Listeria monocytogenes. Industrial Biotechnology. 2013;9(1): 31-36.

224. Zhang G [webpage on the Internet]. Nanostructure-enhanced electron transfer devices for agricultural applications. OECD Conference on Potential Environmental Benefits of Nanotechnology: Fostering Safe Innovation-Led Growth. July 15-17, 2009, OECD Conference Centre, Paris - France. Available from: http://referat.znate.ru/text/ index-42879.html?page=44. Accessed April 19, 2014.

225. Participation of 7 Companies in Agriculture, Packaging Zone in Iran Nano 2013, October 7th, 2013. Available from: http://www.highbeam. com/doc/1G1-344904906.html. Accessed April 19, 2014.

226. Cleveland J, Montville TJ, Nes IF, Chikindas ML. Bacteriocins: safe, natural antimicrobials for food preservation. Int $J$ Food Microbiol. 2001;71(1):1-20.

227. Thirumurugan A, Ramachandran S, Shiamala Gowri A. Combined effect of bacteriocin with gold nanoparticles against food spoiling bacteria - an approach for food packaging material preparation. International Food Research Journal. 2013;20(4):1909-1912.

228. Chen H, Yada R. Nanotechnoogies in agriculture: new tools for sustainable development. Trends Food Sci Technol. 2011;22(11):585-594.

229. Vitaflora [webpage on the Internet]. Benefits with our products. Vitaflora; 2012. Ulica Braće Radić 32 33514, Čačinci Croatia. Available from: vitaflora.hr/benefits-with-our-products. Accessed April 19, 2014.

230. AllAboutFeed.net [webpage on the Internet]. Nano technology in animal feed. Doetinchem: The Netherlands: Reed Business; 2013. Available from: http://www.allaboutfeed.net/Nutrition/FeedAdditives/2013/3/Nano-technology-in-animal-feed-1194836W/. Accessed April 19, 2014.

231. Fondevila M, Herrer R, Casallas MC, Abecia L, Ducha JJ. Silver nanoparticles as a potential antimicrobial additive for weaned pigs. Animal Feed Science and Technology. 2009;150(3-4):259-269.

232. Fondevila M. Potential use of silver nanoparticles as an additive in animal feeding. In: Peres DP, editor. Silver Nanoparticles. Rijeka, Croatia: InTech; 2010:325-334.

233. Pineda L, Sawosz E, Lauridsen C, et al. Influence of in ovo injection and subsequent provision of silver nanoparticles on growth performance, microbial profile, and immune status of broiler chickens. Open Access Anim Physiol. 2012;2012(4):1-8.

234. Kim HJ, Kim SH, Lee JK, et al. A novel mycotoxin purification system using magnetic nanoparticles for the recovery of aflatoxin B1 and zearalenone from feed. J Vet Sci. 2012;13(4):363-369.

235. Organization for Economic Cooperation and Development. 2010. Report of the Questionnaire on Regulatory Regimes for Manufactured Nanomaterials. Paris, France: Organization for Economic Cooperation and Development; 2010.

236. Shi YH, Xu ZR, Feng JL, Wang CZ. Efficacy of modified montmorillonite nanocomposite to reduce the toxicity of aflatoxin in broiler chicks. Animal Feed Science and Technology. 2006;129(1-2):138-148.

237. Kuzma J. Nanotechnology in animal production - upstream assessment of applications. Livest Sci. 2010;130(1-3):14-24.

238. Sutovsky P, Kennedy CE. Biomarker-based nanotechnology for the improvement of reproductive performance in beef and dairy cattle. Industrial Biotechnology. 2013;9(1):24-30.

239. Verma AK, Singh VP, Vikas P. Application of nanotechnology as a tool in animal products processing and marketing: an overview. American Journal of Food Technology. 2012;7(8):445-451.

240. Emami T, Madani R, Rezayat SM, Golchinfar F, Sarkar S. Applying of gold nanoparticle to avoid diffusion of the conserved peptide of avian influenza nonstructural protein from membrane in Western blot. J Appl Poult Res. 2012;21(3):563-566.
241. Solanki K, Grover N, Downs P, et al. Enzyme-based listericidal nanocomposites. Sci Rep. 2013;3:1584.

242. FAO Fisheries and Aquaculture Department, editors. The State of World Fisheries and Aquaculture 2010. Rome, Italy: FAO; 2011.

243. Can E, Kizak V, Kayim M, et al. Nanotechnological applications in aquaculture-seafood industries and adverse effects of nanoparticles on environment. Journal of Materials Science and Engineering. 2011;5: 605-609.

244. ETC Group (Action Group on Erosion, Technology and Concentration) [webpage on the Internet]. Down on the farm: the impact of nanoscale technologies on food and agriculture. Ottawa, ON: ETC Group; 2003. Available from: http://www.nanowerk.com/nanotechnology/reports/ reportpdf/report10.pdf. Accessed April 19, 2014.

245. Zhou X, Wang Y, Gu Q, Li W. Effects of different dietary selenium sources (selenium nanoparticle and selenomethionine) on growth performance, muscle composition and glutathione peroxidase enzyme activity of crucian carp (Carassius auratus gibelio). Aquaculture. 2009;291(1-2):78-81.

246. Rather MA, Sharma R, Aklakur M, et al. Nanotechnology: a novel tool for aquaculture and fisheries development. A prospective mini-review. Fisheries and Aquaculture Journal. 2011;16:1-5.

247. Johari SA, Kalbassi MR, Soltani M, Yu IJ. Toxicity comparison of colloidal silver nanoparticles in various life stages of rainbow trout (Oncorhynchus mykiss). Iranian Journal of Fisheries Sciences. 2013;12(1):76-95.

248. SciDev.Net [webpage on the Internet]. Nanotech filter may protect farmed fish from fungus. London, UK: SciDev.Net; 2013. Available from: http://www.scidev.net/global/news/nanotech-filter-may-protectfarmed-fish-from-fungus.html. Accessed April 19, 2014.

249. Handy RD. FSBI Briefing Paper: Nanotechnology in Fisheries and Aquaculture. Liverpool, UK: Fisheries Society of the British Isles; 2012.

250. Rather MA, Sharma R, Aklakur MD, et al. Nanotechnology: an emerging avenue for aquaculture and fisheries. World Aquaculture. 2011:9-11.

251. The Hindu [webpage on the Internet]. Farmers urged to use nano technology. Chennai, India: The Hindu; 2014. Available from: http:// www.thehindu.com/news/cities/Madurai/farmers-urged-to-use-nanotechnology/article5589631.ece. Accessed April 19, 2014.

252. Li L, Fan MH, Brown RC, et al. Synthesis, properties and environmental applications of nanoscale iron-based materials: a review. Crit Rev Environ Sci Technol. 2006;36(5):405-431.

253. Kong S, Wang Y, Zhan H, et al. Arsenite and arsenate removal from contaminated groundwater by nanoscale iron-manganese binary oxides: column studies. Environ Eng Sci. 2013;30(11):689-696.

254. Bezbaruah AN, Kalita H, Almeelbi T, et al. Ca-alginate-entrapped nanoscale iron: arsenic treatability and mechanism studies. J Nanopart Res. 2014;14(1):1-10.

255. "Altair Nanotechnologies" Algae prevention treatment confirmed effective testing. Market wire 2004. Available from: http://www. investorideas.com/Companies/Nanotechnology/News/Altair0311,04. asp. Accessed April 19, 2014.

256. Gerber LC, Moser N, Luechinger NA, Stark WJ, Grass RN. Phosphate starvation as an antimicrobial strategy: the controllable toxicity of lanthanum oxide nanoparticles. Chem Commun (Camb). 2012;48(32):3869-3871.

257. Li R, Ji Z, Chang $\mathrm{CH}$, et al. Surface interactions with compartmentalized cellular phosphates explain rare earth oxide nanoparticle hazard and provide opportunities for safer design. ACS Nano. 2014;8(2):1771-1783.

258. Jha Z, Behar N, Sharma SN, Chandel G, Sharma DK, Pandey MP. Nanotechnology: prospects of agricultural advancement. Nano Vision. 2011;1(2):88-100.

259. Rajesh Kumar S, Ishaq Ahmed VP, Parameswaran V, Sudhakaran R, Sarath Babu V, Sahul Hameed AS. Potential use of chitosan nanoparticles for oral delivery of DNA vaccine in Asian sea bass (Lates calcarifer) to protect from Vibrio (Listonella) anguillarum. Fish Shellfish Immunol. 2008;25(1-2):47-56. 
260. Rajeshkumar S, Venkatesan C, Sarathi M, et al. Oral delivery of DNA construct using chitosan nanoparticles to protect the shrimp from white spot syndrome virus (WSSV). Fish Shellfish Immunol. 2009;26(3): 429-437.

261. Li L, Lin SL, Deng L, Liu ZG. Potential use of chitosan nanoparticles for oral delivery of DNA vaccine in black seabream Acanthopagrus schlegelii Bleeker to protect from Vibrio parahaemolyticus. J Fish Dis. 2013;36(12):987-995.

262. Myhr AI, Myskja BK. Precaution or integrated responsibility approach to nanovaccines in fish farming? A critical appraisal of the UNESCO precautionary principle. Nanoethics. 2011;5(1):73-86.

263. Gardea-Torresdey JL, Parsons JG, Gomez E, et al. Formation and growth of Au nanoparticles inside live alfalfa plants. Nano Lett. 2002;2(4):397-401.

264. Gardea-Torresdey JL, Gomez E, Peralta-Videa JR, et al. Alfalfa sprouts: a natural source for the synthesis of silver nanoparticles. Langmuir. 2003;19(4):1357-1361.

265. ETC Group [webpage on the Internet]. Down on the farm: the impact of nano-scale technologies on food and agriculture. Ottawa, ON: ETC Group; 2004. Available from: http://www.etcgroup.org/content/downfarm-impact-nano-scale-technologies-food-and-agriculture. Accessed April 19, 2014.

266. Liu N, Huo K, McDowell MT, Zhao J, CuiY. Rice husks as a sustainable source of nanostructured silicon for high performance Li-ion battery anodes. Sci Rep. 2013;3:1919.

267. Marchiol L. Synthesis of metal nanoparticles in living plants. Italian Journal of Agronomy. 2012;7:e37.

268. Cushen M, Kerry J, Morris M, Cruz-Romero M, Cummins E. Nanotechnologies in the food industry - recent developments, risks and regulation. Trends Food Sci Technol. 2012;24(1):30-46.

269. López-Vázquez E, Brunner TA, Siegrist M. Perceived risks and benefits of nanotechnology applied to the food and packaging sector in México. British Food Journal. 2012;114(2):197-205.
270. Suppan S. Nanomaterials in Soil: Our Future Food Chain? Minneapolis, MN: Institute for Agriculture and Trade Policy; 2013. Available from: http://www.iatp.org/files/2013_04_23_Nanotech_ SS.pdf. Accessed April 19, 2014.

271. Boholm M, Arvidsson R. Controversy over antibacterial silver: implications for environmental and sustainability assessments. J Clean Prod. 2014;68:135-143.

272. Wang Q, Ma X, Zhang W, Pei H, Chen Y. The impact of cerium oxide nanoparticles on tomato (Solanum lycopersicum L.) and its implications for food safety. Metallomics. 2012;4(10):1105-1112.

273. Chaudhry Q, Scotter M, Blackburn J, et al. Applications and implications of nanotechnologies for the food sector. Food Addit Contam Part A Chem Anal Control Expo Risk Assess. 2008;25(3): $241-258$

274. Momin JK, Jayakumar C, Prajapati JB. Potential of nanotechnology in functional foods. Emirates Journal of Food and Agriculture. 2013;25(1):10-19.

275. Sastry RK, Rashmi HB, Rao NH, Ilyas SM. Integrating nanotechnology into agri-food systems research in India: a conceptual framework Technol Forecast Soc Change. 2010;77(4):639-648.

276. European Commission. Commission Delegated Regulation (EU) No .../.. of 12.12.2013 Amending Regulation (EU) No 1169/2011 of the European Parliament and of the Council on the Provision of Food Information to Consumers as Regards the Definition of 'Engineered Nanomaterials'. European Commission. Brussels, Belgium; 2013. Available from: http:/www.europarl.europa.eu/meetdocs/2009_2014/ documents/envi/dv/envi20140212_dea_nano_/envi20140212_dea_ nano_en.pdf. Accessed April 19, 2014.

277. Schlyter C, Westlund A, Liotard KT, Klaß C, Pietikäinen S, Ries F. Motion for a Resolution. Brussels, Belgium: European Parliament; 2014. Available from: http://www.europarl.europa.eu/ meetdocs/2009_2014/documents/envi/re/1015/1015222/1015222en. pdf. Accessed April 19, 2014.
Nanotechnology, Science and Applications

\section{Publish your work in this journal}

Nanotechnology, Science and Applications is an international, peerreviewed, open access journal that focuses on the science of nanotechnology in a wide range of industrial and academic applications. It is characterized by the rapid reporting across all sectors, including engineering, optics, bio-medicine, cosmetics, textiles, resource sustainability

\section{Dovepress}

and science. Applied research into nano-materials, particles, nanostructures and fabrication, diagnostics and analytics, drug delivery and toxicology constitute the primary direction of the journal. The manuscript management system is completely online and includes a very quick and fair peer-review system, which is all easy to use. 